\title{
A SZOVJET-KOMMUNISTA SAJTÓMODELL SAJÁTOSSÁGAI ÉS KORSZAKAI MAGYAR- ORSZÁGON 1956 ÉS 1990 KÖZÖTT
}

\author{
Kékesdi-Boldog Dalma \\ boldog.dalma@gmail.com \\ D O I : $10.20520 /$ J E L - K EP.2021.1.53
}

\begin{abstract}
Absztrakt
A magyar államszocializmus évei alatt a tájékoztatáspolitika retorikai szinten mindvégig követte a marxista-leninista alapelveket és a szovjet-kommunista sajtómodellt. A tömegkommunikáció tartalmi, előállítási és terjesztési körülményei a szovjet modellhez hasonlóan szigorú pártállami irányítás és -befolyás alatt álltak. Hasonlóságot mutat a sajtó hierarchikus szervezeti felépítése is. Ugyanakkor a tömegkommunikáció gyakorlati irányítása nem követte pontosan a szovjet mintát, így a magyar tájékoztatáspolitika több lokális sajátossággal is bírt. Dolgozatomban a domináns kül- és belpolitikai tényezőkkel és a társadalmi, gazdasági problémákkal összefüggésben a Kádár-korszak tájékoztatáspolitikájának hat nagy korszakának ismertetésére teszek kísérletet.
\end{abstract}

\section{Kulcsszavak}

Magyar Szocialista Munkáspárt, Kádár-korszak, szovjet-kommunista sajtómodell, tájékoztatáspolitika

\section{PARTICULARITIES AND PERIODS OF THE SOVIET-COMMUNIST PRESS MODEL IN HUNGARY BETWWEN 1956 AND 1990}

Dalma Kékesdi - B oldog

\begin{abstract}
While the Hungarian Socialist Workers' Party was rhetorically committed to the Soviet agitation and propaganda model, its actual practice increasingly deviated from it. The regulation methods of mass communication were under strict state control. The hierarchical organisational structure of the press was also similar to the Soviets. But the Hungarian practice of the press-guidance was a bit different, because of some local and global political, social and economic effects. In this paper I attempt to characterise the six main eras of the information policy of the Kádár regime.
\end{abstract}

\section{Keywords}

Hungarian Socialist Workers' Party, information policy, Kádár Regime, Soviet-communist press system 


\title{
A SZOVJET-KOMMUNISTA SAJTÓMODELL SAJÁTOSSÁGA I ÉS KORSZAKAI MAGYAR - ORSZÁGON 1956 ÉS 1990 KÖZÖTT ${ }^{1}$
}

\author{
Kékesdi-Boldog Dalma
}

\section{Bevezetés: A Kádár-kori tájékoztatáspolitika hat korszaka}

A szovjet-kommunista típusú sajtómodell különbözőképpen, más hangsúlyokkal valósult meg a szovjet csapatok által megszállt és ellenőrzés alá vont kelet-közép-európai államokban (Bajomi-Lázár et al. 2020). Magyarországon három fő korszakot lehet megkülönböztetni a tájékoztatási gyakorlat terén: a Rákosi-korszakot, az 1953 és az 1956 közötti átmeneti időszakot és a Kádár-korszakot. Ez utóbbit a vezető szakirodalmi források (például Hegedűs 2001, Takács 2009, 2012, 2015, Buzinkay 2016) jellemzően két részre osztják: a forradalom utáni megtorlás éveire és a konszolidált Kádár-korszakra, ám ez utóbbit a kutatók nem szakaszolják tovább. Úgy vélem, a Kádár János nevével jegyzett három évtizedes éra tájékoztatáspolitikailag sem tekinthető egységesnek, mert több esetben figyelhető meg irányváltás a tömegkommunikáció elméleti és/vagy gyakorlati irányításban.

Tanulmányomban előbb röviden áttekintem a szovjet-kommunista sajtómodell jellemzőit (Siebert et al. 1956/1984), majd ismertetem e sajtómodell magyar változatát és bemutatom a Kádár-korszak hat nagy tájékoztatáspolitikai időszakát. A magyar tájékoztatáspolitika alakulását a lokális és a globális politikai események tükrében vizsgálom, és arra a kérdésre keresek választ, hogy a politikai rendszer milyen változásai magyarázzák a tájékoztatáspolitika alakulását. A tájékoztatáspolitikai attitüdöket és motivációkat elsődlegesen a pártkongresszusi határozatok és a párt agitációról és propagandáról, valamint a sajtó, a rádió és a televízió müködéséről és feladatairól szóló határozatai alapján igyekszem feltárni. Elsősorban a nyomtatott sajtó és az elektronikus média irányításának jellegzetességeit emelem ki, a második nyilvánosságban zajló tevékenységre csak érintőlegesen térek ki (erről lásd például Sükösd 2013, Jakab 2015), a kulturális-szellemi élet és a müvészetek irányítását illetően csak a legrelevánsabb forrásokat ismertetem. Az oktatási, a müvelődési és a tudománypolitikai koncepciókat terjedelmi okokból kifolyólag itt most nem tárgyalom (erről lásd például Glatz 2002, Gombár 2009, Kalmár 2014, Darvai 2015). A Kádár-korszak szakaszolása során kiindulópontként a Fricz Tamás (1988) által javasolt korszakhatárokat használom, de az általa megjelölt dátumokat és fogalmakat kritikával kezelem. ${ }^{2}$ A tájékoztatáspolitika sajátosságait a

1 Jelen publikáció az Innovációs és Technológiai Minisztérium ÚNKP-20-3-II-CORVINUS-31 kódszámú Új Nemzeti Kiválóság Programjának a Nemzeti Kutatási, Fejlesztési és Innovációs Alapból finanszírozott szakmai támogatásával készült.

${ }^{2}$ Két esetben eltérek a Fricz által javasolt korszakhatároktól, ezt a későbbiekben lábjegyzet formájában jelölöm. A Fricz által demokratizációként definiált folyamatokra a politikatudományi-tranzitológiai terminológiát követve a liberalizáció kifejezést használom A nem demokratikus államokban 
primér források mellett más szerzők (Békés 2019, Buzinkay 2016, Földes 2018, Hegedűs 2001, Kalmár 2014, Takács 2008, 2012, 2015) kutatási eredményeivel kiegészítve írom le. Fontosnak tartom megjegyezni, hogy annak ellenére, hogy találunk a tájékoztatáspolitika alakulására közvetlenül hatással bíró kül- és belpolitikai tényezőket, nehéz egyetlen évszámhoz vagy az adott év első és utolsó napjához kötni a változás kezdetét és végét. Egy-egy határozat létrejöttét hosszabb előkészítési folyamat előzte meg - amely már önmagában jelezheti a változást -, így az gyakran nem az érvénybe lépése idején, hanem később fejtette ki hatását. Az itt megjelölt dátumok ezért inkább viszonyítási pontokként szolgálnak. A kutatói szándék jelen esetben nem az évszámok kőbe vésése, hanem a tendenciák jelzése és a Kádár-korszak médiairányításának továbbgondolása.

\section{A szovjet-kommunista típusú tájékoztatáspolitika jellemzői}

A szovjet-kommunista típusú tájékoztatáspolitika a tekintélyelvű sajtómodellek egyik változata (Siebert et al. 1956/1984). ${ }^{3}$ A tekintélyelvü sajtómodell alapelve az, hogy a közönség nem képes önállóan megismerni és értelmezni a világ dolgait, ezért a sajtónak az a feladata, hogy a tájékoztatás mellett értelmezzen és orientáljon is. A médiarendszer ezért a politikai rendszert kiszolgáló, folyamatos kontrol alatt álló intézményként müködik, és fő feladata a hatalom társadalmi legitimációjának biztosítása. A szovjet-kommunista típusú sajtómodellben a tömegek elérését szolgáló valamennyi kommunikációs csatorna pártállami monopóliumban volt. Ebben a modellben az információáramlás felülről lefelé zajlott, így a kommunikációs csatornák nem a hatalom társadalmi ellenőrzését szolgálták, hanem a társadalom politikai ellenőrzését (Lázár 1988/2006: 25). A sajtó politikai instrumentalizációja ${ }^{4}$ az államszocialista

a liberalizáció úgy definiálható, mint a politikai és társadalmi változások keveredése. Liberalizációra utaló jelenség például a médiarendszer tartalmának a korábbiaknál kisebb mértékủ cenzúrázása, a munkásosztály tevékenységei feletti kontroll enyhülése, a valamivel nagyobb tér biztosítása, bizonyos jogi szabályozók és biztosítékok bevezetése, a politikai foglyok szabadon bocsátása, a száműzöttek visszafogadása, a jövedelemelosztást javító intézkedések bevezetése és az ellenzék tolerálása (Linz - Stepan 1996: 3).

3 Tanulmányomban a Fred Siebert, Theodore Peterson és Wilbur Schramm által jegyzett $A$ sajtó négy elmélete címü munkára támaszkodom a szovjet típusú tájékoztatáspolitika leírása során. Sieberték két kategóriát határoltak el egymástól: a tekintélyelvü és a szabadelvü sajtómodellt, ezeken belül pedig két további altípust neveztek meg: a társadalmifelelősség- és a szovjet-kommunista modellt. A mü 1956-ban jelent meg, így a szerzők értelemszerủen nem számolnak a tömegkommunikációs eszközök fejlődésével, az infokommunikációs forradalommal, a globalizációval. Az elemzés magán viseli a hidegháborús diskurzusból származó Nyugat-Kelet oppozíciót, továbbá a szerzők nem veszik figyelembe a földrajzi, a gazdasági, a vallási, az etnikai és az egyéb társadalmi törésvonalakat sem. Mindezek ellenére a tekintélyelvü és a szabadelvü distinkció évtizedek múltával is a médiarendszerirodalom egyik megkerülhetetlen felvetése, és azóta is számos tudományos értekezés kiindulópontját jelenti.

${ }^{4}$ A tömegkommunikáció eszközelvü használatán, vagyis a média politikai instrumentalizációján Daniel C. Hallin és Paolo Mancini nyomán azt a folyamatot értem, amelynek során a nyomtatott sajtót és az elektronikus médiát külső tényezők befolyásolják annak érdekében, hogy a tömegkommunikáción keresztül hatást gyakoroljanak a politikai rendszerre (Hallin - Mancini 2004/2008: 51). A lehetséges külső tényezők - pártok, politikusok, társadalmi csoportok vagy mozgalmak, politikai befolyásra törő gazdasági szereplők, kereskedelmi érdekeltségek - közül ez esetben a tekintélyelvü sajtómodell sajátosságai miatt az uralkodó politikai párt által végrehajtott politikai instrumentalizáció írható le. Ebben a helyzetben a párt formális és informális rendelkezésekkel, jogi szabályozókkal hatással van a sajtó tartalmára annak érdekében, hogy az csak a párt nézeteit terjessze, politikáját propagálja. 
ideológia fenntartását és az állampárt legitimálását szolgálta. A párt nemcsak politikai iránymutatásokkal korlátozta a tömegkommunikációs eszközök müködését, hanem aktívan használta is azokat propagandacéljaira (Siebert et al. 1956/1984: 27-28).

A szovjet tömegkommunikáció irányítása négy fő alapelv mentén zajlott. Ezek közül az első a kommunista pártosság (партийность - partijnoszty), amely azt fejezi ki, hogy a médiarendszer szoros kapcsolatban áll a politikai rendszerrel, és tartalma pártállami ellenőrzés alatt áll azért, hogy a média a párt által meghatározott értékeket és normákat közvetítse az embereknek. Ahogyan Lenin fogalmazott: „Az újság szerepe nem szorítkozik csak az eszmék terjesztésére, politikai nevelésre és politikai szövetségesek szerzésére. Az újság nemcsak kollektív propagandista és kollektív agitátor, hanem kollektív szervező is." (Lenin - Sztálin 1901/1948: 33). Míg Lenin csak megfogalmazta a párt tömegkommunikációval szembeni elvárásait, Sztálin keményen végre is hajtotta azokat: ő építette fel az államilag ellenőrzött és szigorú elnyomáson alapuló tájékoztatáspolitikai rendszert (Brooks 2000: xiv). Olyan „bürokratikus nyilvánosságot" hozott létre, amelyben elsősorban alkotó, vagyis nem a megtörtént eseményeket értelmező, hanem az eseményeket teremtő propagandát alkalmazták. Ebben a nyilvánosságban a propaganda elsőbbséget élvezett a tájékoztatással szemben, és uralma alá vonta az irodalmi és müvészeti szférát is (Lázár 1988/2006: 25-26). A második alapelv $a$ kommunista objektivitás (объективность - objektivnoszty), amely nem azonos a pártatlansággal. Ez az „objektivitás” azt jelentette, hogy a világ dolgainak leírása és értelmezése a médiában kizárólag az SZKP érdekeinek megfelelően történhet. A harmadik alapelv a néppel való kapcsolat, a tömeges elérhetöség (народность - narodnoszty, массовость - masszovoszty), amelynek értelmében a médiarendszer feladata az, hogy széles körben elérhető legyen, kapcsolja össze a pártot a tömegekkel, és platformként szolgáljon az alulról jövő vélemények közvetítéséhez. A negyedik elem a nyitottság (гласность - glasznoszty). Ezt a XIX. században I. Miklós orosz cár is alkalmazta, akkor a társadalmi és gazdasági változásokra irányuló véleménycserét jelentette. Lenin már pozitív glasznosztyról és kritikai glasznosztyról értekezett: az előbbi a média a kommunizmus építését és népszerüsítését szolgálja, az utóbbi pedig a gazdasági és a társadalmi jelenségekkel kapcsolatos kritika és önkritika nyilvános megfogalmazásának lehetőségét biztosítja (McNair 1991: 23). A szovjet típusú sajtómodellben csak a párt által meghatározott kritika jelenhetett meg, és ezt feltétel nélkül el kellett fogadni, mert ennek elutasítása a döntések megalapozottságának megkérdőjelezését jelentette volna (Lázár 1988/2006: 27). Ebben Mihail Gorbacsov - aki szerint a gazdasági átalakulás nem lehet sikeres politikai megújulás és önkritika-gyakorlás nélkül (Taylor 2013: 6) - glasznoszty fogalma hozott bizonyos fokú változást, amely a politikai nyitottságot, a politikai participációt és a konstruktív vitát jelentette (McNair 1991: 15-23). Ennek hatására némileg bővült a nyilvános szférában megtürt tartalmak köre, csökkent a hivatalosan tabusított témák száma, és valamelyest nőtt a szerkesztőségek mérlegelési lehetősége (Gibbs 1999: 8). Ám a politikai rendszerrel, illetve a Gorbacsovval szemben megfogalmazott kritikák, valamint a valódi problémák nem kaphattak nyilvánosságot.

\section{Az 1956 utáni magyar tájékoztatáspolitika jellemzői}

A magyar médiarendszer sosem fejlődött önállóan, hanem - az ország geopolitikai helyzete miatt - mindig külső modelleket követett (Bajomi-Lázár 2020: 160). Az 1956 utáni magyar tájékoztatáspolitika a szovjet-kommunista sajtómodell egyik változata volt, amely felépítését és alapelveit tekintve nagyon hasonló volt a Szovjetunióbéli tájékoztatáspolitikához, de több sajátos vonással is bírt.

A Szovjetunió Kommunista Pártjához hasonlóan a Magyar Szocialista Munkáspárt (MSZMP) is azt deklarálta, hogy a sajtó feladata a lakosság véleményének befolyásolása, a 
pártpolitika helyességéről való meggyőzése és az aszerint való cselekvés ösztönzése. Vagyis a tömegkommunikációnak biztosítania kellett a politikai ideológia folyamatosságát és a párt legitimációját.

A magyar tömegkommunikációs eszközök a szovjetekhez hasonlóan pártállami tulajdonban voltak, és állambiztonsági ellenőrzés alatt álltak. Pártállami monopólium volt a hírközlésben a Magyar Távirati Iroda (MTI) hegemóniája révén. Az MTI politikai-ideológiai irányítása döntően befolyásolta a híranyagokhoz való hozzáférést, és az itt kiadott jelentések gyakran a szóhasználatot is meghatározták (Hegedüs 2001: 51). Állami monopólium volt az újságíróképzés, a szerkesztőségek, a kiadók és a nyomdák müködtetése. Az államnak monopóliuma volt a sajtótermékek előállításának infrastrukturális feltételeiben is a lapalapítás korlátozása, a rádió- és televízió-frekvenciahullámok állami tulajdonba vétele, valamint a papírellátás feletti kizárólagos rendelkezési jog révén (Bajomi-Lázár 2005: 28-31).

A párt nómenklatúrarendszert épített ki, amelyben a felelős vezetői pozíciók kijelölése során nem feltétlenül a szaktudás vagy a rátermettség, inkább a párttagság, az állambiztonsági értelemben vett megbízhatóság, valamint a párt befolyásos vezetőivel való informális kapcsolat volt a meghatározó szelekciós tényező. További jellemző volt a patrónusi-kliensi rendszer müködtetése is, amely szívességek és az elkötelezettségek bonyolult viszonyrendszerét alakította ki az évek során (Buzinkay 2016: 429).

A hazai tájékoztatáspolitikának vannak sajátos vonásai is. Az egyik legjellemzőbb ezek közül a konzekvens jogszabályi háttér hiánya miatt kialakult szabályozatlanság. A sajtóirányítás nem egy világosan megfogalmazott sajtótörvény értelmében valósult meg - sajtótörvényre egészen 1986-ig várni kellett -, hanem az MSZMP vezető szervei által kiadott határozatok, rendeletek alapján történt. Ezek a dekrétumok és kisebb jelentőségü rész- és határterületeket érintő döntések elsősorban nem a sajtó jogi szabályozását, hanem politikai irányítását szolgálták (Takács 2015: 492). Az 1986. évi sajtótörvény érvénybe lépéséig az 1949-es alkotmány vonatkozó része, illetve néhány általános irányvonalat kijelölő párthatározat szabta meg a sajtómüködés kereteit (Bayer 2005: 159-166). Az 1949-es alkotmányban az állt, hogy: „A Magyar Népköztársaság a dolgozók érdekeinek megfelelően biztosítja a szólásszabadságot, a sajtószabadságot, a gyülekezési szabadságot." ${ }^{, 5}$ Az 1958-as párthatározat pedig így rendelkezett a sajtóval szembeni tartalmi elvárásokról: „A sajtó legyen pártos, munkájában álljon fenntartás nélkül a proletárdiktatúra talaján, álláspontja legyen mindig osztályálláspont”. ${ }^{2} \mathrm{Ez}$ az elvárás 1979-ben a következő lényegi elemmel bővült: „Arra kell törekedni, hogy a sajtó, a rádió, a televízió nagy felelősséggel, politikai-szakmai felkészültséggel tegyen eleget a hiteles, pontos, gyors tájékoztatásnak."7 Bár ebben a határozatban már szerepelt a hitelesség, valódi változást csak az 1986-os sajtótörvény hozott, amelyből kikerült a pártosság mint elvárás, és már ,a hiteles és pontos” tájékoztatás eszményét fogalmazta meg. ${ }^{8}$

A kiszámíthatatlanságot fokozta az is, hogy bár hivatalosan nem volt cenzúra, a tömegkommunikáció irányítása számos közvetlen és közvetett beavatkozáson keresztül zajlott (Bajomi-Lázár 2005: 28-31). A sajtótervek elöre meghatározták a sajtó politikai napirendjét, illetve azt, hogy egy adott eseményröl hogyan és mit lehetett kommunikálni. A hírközlés inf-

5 1949. évi XX. törvény. A Magyar Népköztársaság Alkotmánya 55. § (1), (2).

${ }^{6}$ Az MSZMP Központi Bizottsága Politikai Bizottságának határozata a sajtó helyzetéről, feladatairól (1958. január 21.) (Vass - Ságvári 1964: 197).

7 Az MSZMP Központi Bizottsága Politikai Bizottságának határozata az agitációs munka helyzetéröl, időszerü feladatairól (1979. március 27.) (Vass 1983: 945).

8 1986. évi II. törvény a sajtóról $2 \S(1)$. 
rastrukturális feltételeinek és intézményrendszereinek állami tulajdonba vétele, és a személyzeti politika kialakítása a közvetett irányítás része volt, de ide tartozik a „kényes” kül- és belpolitikai témák (mint például az 1956-os forradalom, a prágai tavasz, a szegénység, a társadalmi devianciák, a droghelyzet stb.) tabusítása, valamint az Aczél György nevével fémjelzett differenciált kultúr- és információs politika is, az úgynevezett „3T”. Ez a klasszifikációs rendszer a „türt”, a „tiltott” és a „támogatott” kategóriák mentén osztályozta a nyilvános kommunikáció - a kultúra és a tömegkommunikáció - tartalmát. A „3T” nem volt egyértelmü osztályozási rendszer, ugyanis nem mindig volt világos az, hogy a támogatás vagy a türés a szándékolt átpolitizálás és a cenzúra, vagy éppen a liberalizálás eszköze volt-e (Sipos 2015: 36-38). Az Aczél-féle kultúrpolitika regionálisan egyedülálló volt abban az értelemben, hogy aktív (nép)nevelési, oktatási szándékkal fordult a társadalom széles köréhez, és egy személyesnek mondható, atyáskodó jellegü kommunikációs stratégián keresztül valósult meg (Kalmár 2017). Ám az osztályozás szubjektivitáson és a kliensi-patrónusi rendszer személyes kapcsolatain alapult, és Aczél nem zárkózott el a határozott lépésektől sem (Buzinkay 2016: 429).

A jogi szabályozatlanság és a közvetlen tájékoztatáspolitikai intézkedések növelték az újságírói bizonytalanságot, és gyakran egzisztenciális fenyegetettséggel jártak (Bajomi-Lázár 2005: 22). Rendszeresek voltak a szerkesztőségi telefonhívások, és gyakran éltek az „utólagos rendteremtés" eszközével is: például a föszerkesztői magyarázkodást szolgáló, úgynevezett igazoló jelentések kikövetelésével, a személyes „elbeszélgetésekkel”, vagy a prémiummegvonással (Bozóki 1996: 65, Murányi 2000a, 2000b). De volt példa a nyomdából kikerült lapok bezúzására is, egyebek között 1983-ban a História, 1985-ben a Mozgó Világ, 1986-ban a Liget esetében. Közvetlen politikai befolyásolást jelentett a külföldi rádióadások frekvenciájának zavarása is.

\section{A Kádár-korszak hat nagy tájékoztatáspolitikai időszaka}

A forradalom leverése után, 1956 novemberében szovjet támogatással Kádár János került hatalomra, és megalakult a Magyar Szocialista Munkáspárt (MSZMP). A Kádár-korszak a több mint három évtizede alatt nemcsak politikailag volt fragmentált, hanem - mint azt látni fogjuk a tájékoztatáspolitika müködését tekintve sem volt egységes.

\section{A forradalom leverése utáni évek (1957-1959)}

Az 1957 és 1959 közötti időszakra az erőskezü irányítás és a hatalomátvétel utáni rendteremtés volt a jellemző. Mindennapos volt a szigorú állambiztonsági ellenőrzés és a megfélemlítés. A külpolitikában Kádár a szovjet-magyar kapcsolatok megerősítésére fókuszált: miután eleget tett a szovjet elvárásoknak, és biztosította a SZKP vezetését arról, hogy a forradalmi események nem fognak megismétlődni, kérte a romokban levő magyar gazdaság megsegítését, amely végül deviza- és áruhitel, valamint adósságelengedés formájában meg is valósult 1957-ben (Földes 2015: 24-25).

A forradalom leverését és a szovjet csapatok bevonulását követően a hatalom centralizációja során a sajtóirányításban (is) szükség volt a jogi szabályozók bevezetésére és az intézményi apparátus felállítására. Az 1956. december 19-én kelt kormányrendelet rendelkezett a Tájékoztatási Hivatal - újbóli ${ }^{9}$ - megalapításáról. Ez „a Kormány elnökének közvetlenül

9 Nagy Imre miniszterelnök 1954 tavaszán rendelkezett a Tájékoztatási Hivatal felállításáról, amelynek fó feladata a párt politikájának nyilvános képviselete volt; a gyakorlatban ez a sajtó munkatársai 
alárendelve" az alábbi feladatokat látta el: az állami tájékoztatási munka megszervezése, a hivatalos határozatok, rendeletek, kommünikék, törvények továbbítása a sajtónak, valamint a sajtórendészeti tennivalók ellátása. ${ }^{10}$ A sajtórendészeti feladatok közé tartozott a lapengedélyek kiadása vagy bevonása, a külföldröl érkező sajtótermék terjesztésének engedélyezése, a papírigények számbavétele és biztosítása, a lapfejlesztési tervek kidolgozása is. A Tájékoztatási Hivatal felügyelete alá tartozott a Magyar Rádió és Televízió, a Magyar Távirati Iroda, a Magyar Újságírók Országos Szövetsége, a Magyar Újságírók Szanatóriumi Egyesülete és a négy lapkiadó vállalat.

Kádár a közvetett, elsősorban a szerkesztői felelősségre építő cenzúrarendszert preferálta. Ezt az MSZMP VII. kongresszusán a következőképpen fogalmazták meg: „A párt munkastílusának fontos, új vonása a helyi pártszervek és a pártmunkások önállóságának növekedése, a felesleges gyámkodás, a tömeges utasítgatás csökkentése." ${ }^{11}$ Az új típusú irányítás első lépéseként 1958-tól rendszeresítették a főszerkesztői értekezleteket, ahol közzétették az általános tudnivalókat, a párt szerveinek utasításait, döntéseit. Ezeken zajlott a „lapbírálat” is, vagyis a kiadott sajtócikkek utólagos cenzúrája, amelynek során a sajtó munkatársai értesültek egy-egy konkrét anyaggal kapcsolatban a pártvezetés kritikai megjegyzéseiről, elmarasztalásáról, jövőbeli javaslatairól (Cseh et al. 1999: 224-225).

Míg az 1953-as desztalinizációs politika hatására a Szovjetunióban a korábbiakhoz képest tájékoztatáspolitikai enyhülés vette kezdetét, és a korábbi évekhez képest tapasztalható lett a tömegkommunikáció politikai függetlenedése és tartalmi színesedése (McNair 1991: 3, Sakwa 1999: 305, Taylor 2013: 5), addig az MSZMP a tájékoztatáspolitikában vonalas propagandafeladatokat határozott meg: a tömegkommunikációs eszközök feladata a befolyásolás, az agitáció és az államszocialista propaganda terjesztése. A sajtónak az orientálás mellett tudatos „,népnevelöi feladatokat” is el kellett látnia, „meg kellett győzni a párt politikájának helyességéről”, és szerepet kellett vállalnia „a társadalmi mozgósításban” is. ${ }^{12}$ A médiairányítás szempontjából fontos felismerés fogalmazódott meg a Politikai Bizottság 1958-as, sajtóval kapcsolatos határozatában: „Egyes vezető funkcionáriusok még ma is lebecsülik a sajtó politikai jelentőségét. ... Még mindig vannak olyan vezető funkcionáriusok, akik félnek a nyilvánosságtól." 13 Vagyis a tájékoztatáspolitikában kifejezésre jutott a sajtó politikai instrumentalizációs szándéka.

1958-ban kiadták „A MSZMP Művelődési Politikájának Irányelvei” című dokumentumot, amelynek fó célja a párt és a müvészértelmiség (érdek)kapcsolatának szorosabbá füzése volt. Világossá tették, hogy ,,az irányítás fö eszköze az eszmei befolyásolás”, amelyben „,jelentős szerepe van a kulturális élethez szükséges anyagi-technikai eszközök biztosításának és helyes elosztásának." 14 Ugyanebben a szövegben fogalmazódott meg először a kultúrpolitika differenciálódásának elve is, vagyis az, hogy a támogatás és a tiltás mellett megjelenhet a megtürés is. A határozat „tudományos” alapokra helyezte a müvelődést, megszüntette a kultúrpolitikában az irodalomcentrikus nézőpontot, és új ösztönzőrendszert épített ki (Kal-

számára sajtótájékoztatók, eligazítások szervezését jelentette (Takács 2015: 402). A hivatalt Rákosi Mátyás számolta fel 1955-ben, majd egy évvel később ismét felállították azt (Takács 2009).

${ }^{10}$ A Magyar Forradalmi Munkás Paraszt Kormány 25/1956. (XII. 19.) számú határozata a Kormány Tájékoztatási Hivatalának megszervezéséröl. Magyar Közlöny, 104. sz. 1956. december 19. 603. o.

${ }^{11}$ A Magyar Szocialista Munkáspárt VII. kongresszusa (1959. november 30. - december 5.) 167. o.

${ }^{12}$ Az MSZMP Központi Bizottsága Politikai Bizottságának határozata a sajtó helyzetéről, feladatairól (1958. január 21.) (Vass - Ságvári 1964: 199).

${ }^{13}$ Uo. 164. o.

${ }^{14}$ Az MSZMP Müvelődési Politikájának Irányelvei (1958. július 25.) (Vass - Ságvári 1964: 308). 
már 2014: 150). Ezzel párhuzamosan rögzítette az MSZMP vezető szerepének megkérdőjelezhetetlenségét, illetve azt, hogy a párt ellen mindennemü fellépést és éles hangú kritikát a szocializmus elleni támadásként értelmez és keményen fellép ellene (Földes 2018: 213). Ez a differenciált kultúr- és tájékoztatáspolitikai attitüd egy évtizeddel később szilárdult meg, miután Aczél György fokozatosan a kulturális-ideológiai élet meghatározó alakjává vált.

A sajtómüködés átfogó jogi szabályozásáról a 26/1959. (V. 1.). számú kormányrendelet határozott, amely definiálta a sajtótermék fogalmát, szabályozta elöállítási, sokszorosítási és terjesztési folyamatát, kimondta az impresszum feltüntetésének kötelezettségét, továbbá tájékoztatott az engedélyezési folyamatról, a helyreigazítás menetéról és a szabálysértési tényállásokról. ${ }^{15}$ Ez az utasítás, illetve ennek az idők során kiegészített, módosított változta az 1986-os sajtótörvény bevezetéséig volt érvényben (Cseh et al. 2004: 279).

\section{Konszolidációs időszak (1960-1964)}

1961-ben az SZKP XXII. kongresszusán Nyikita Szergejevics Hruscsov kihirdette a kommunizmus építésének időszakát, és hangsúlyozta a békés egymás mellett élés fontosságát. ${ }^{16} \mathrm{~A}$ kommunizmus építése feltételezte azt, hogy a szocialista országok közel egy időben érik el a kívánt gazdasági, infrastrukturális, életszínvonalbeli, társadalmi fejlettségi szintet, ami egyrészt lehetetlen elvárás volt, másrészt viszont kedvezett a magyar pártvezetésnek, mert hivatkozási alapot biztosított a kibontakozóban lévő hazai modernizációs kísérletek meggyorsításához, illetve az ehhez szükséges szovjet és nyugati hitelek igényléséhez (Földes 2015: 5255). Az SZKP XXII. kongresszusának hatására valamelyest enyhült a szovjet-amerikai külpolitikai viszony, Magyarországon pedig háttérbe szorultak a hatalmi-politikai harcok. Az MSZMP vezetése nagyobb mozgástérhez jutott, és engedékenyebb hozzáállást mutatott, mint a megelőző években; ezzel az volt a célja, hogy az értelmiséget a párt programja mellé állítsa (Lehmann 1998: 2). Az 1963. évi tavaszi országgyülési és tanácsválasztások eredménye megteremtette az MSZMP konszolidációját. Az ugyanebben az évben meghirdetett amnesztiarendelet pedig - amely „emberisségtől áthatva” kegyelmet adott és társadalmi beilleszkedést ajánlott az ,államellenes vagy ellenforradalmi tevékenység” miatt elítélteknek - a békés egymás mellett élést és a nyugodt életkörülményeket deklarálta. ${ }^{17}$ Ennek hatására - több titkos előkészítő magyar-amerikai diplomáciai tárgyalást követően, amerikai kezdeményezésre lekerült az ENSZ Közgyülés napirendjéről a „magyar ügy”, vagyis az 1956-os forradalom leverése (Király 2006: 46). Ekkoriban terjedt el Kádár János „Aki nincs ellenünk, az velünk van" jelmondata is (Takács 2008: 160), amelyet nem csak a belpolitikai viszonyokra vonatkozva érvényesített a pártvezetés; ez az attitüd az MSZMP VII. kongresszusától kezdve a külpolitikai stratégia fontos alappillérévé is vált. ${ }^{18}$

A kül- és belpolitikai enyhülés a tömegkommunikáció funkciójának értelmezésében is változást hozott. Oldódott a harcias, szenvedélyes hangvétel, a sajtó pedig a propagandista újságírás helyett inkább tájékoztatási, politikai-kulturális nevelési célzattal müködött. Ezt az MSZMP VIII. kongresszusán így fogalmazták meg: „Azt várjuk, hogy a sajtó, a rádió és a televízió munkatársai igényesebben, vonzóbb formában hirdessék a szocializmus igazságait.

${ }^{15}$ 26/1959. (V. 1.) Korm. rendelet a sajtóval kapcsolatos egyes kérdésekröl. Magyar Közlöny, 49. sz. 1959. május 1. 329. o.

${ }^{16}$ Az SZKP XXII. kongresszusa, Párttörténeti Közlemények. Az MSZMP Központi Bizottsága Párttörténeti Intézetének Folyóirata, VII. évf. 4. sz. 1961. november 1. o.

${ }^{17}$ ÁBTL-4.2.-1963. évi 4. tvr. a közkegyelem gyakorlásáról.

${ }^{18}$ A Magyar Szocialista Munkáspárt VII. kongresszusa (1959. november 30. - december 5.) 11. o. 
Legyenek a szocialista ember nevelésének, az egységes szocialista társadalom formálásának élenjáró munkásai, terjesszék a szocialista kultúrát." ${ }^{19}$ A kongresszus határozatában az irodalom és a müvészetek vonatkozásában az is kifejezésre jutott, hogy a pártvezetés a kulturális fejlődés érdekében teret ad „minden más jó szándékú, nem ellenséges müvészeti tevékenységnek is" ${ }^{20}$, vagyis halványan, de ismét körvonalazódott, hogy a nyilvános szférában létezik egy „megtürt” kategória is. Lényeges előrelépést jelentett, hogy 1963 decemberében technikai, gazdasági és politikai okokra hivatkozva ${ }^{21}$ döntés született a nyugati rádióállomások - a BBC, az Amerika Hangja, a Szabad Európa Rádió magyar adása - zavarásának átmeneti megszüntetéséröl. ${ }^{22}$

\section{Reformok és liberalizáció (1965-1970)}

1964-ben az SZKP váratlanul leváltotta a párt éléről Kádár személyes jó barátját, Hruscsovot, akinek helyére a neosztálinista kultuszt meghonosító Leonyid Iljics Brezsnyev került. Az új típusú politikai irányítás következtében a médiarendszer liberalizálása a Szovjetunióban és Magyaroroszágon is visszaesett, és az elvi irányításban és a tömegkommunikáció technológiai fejlődésében stagnálás vette kezdetét (McNair 1991: 35). Kádár nem titkolta megdöbbenését, és hosszas bírálatban hozta Brezsnyev tudomására egyet nem értését (Békés 2019: 183-184).

Ezt követően tudatos külpolitikai stratégiaváltás következett, mert a magyar belpolitikában a gazdaság átstrukturálása vált központi kérdéssé. Az 1966-os év végén az MSZMP IX. Kongresszusán döntés született a gazdasági reform bevezetéséről: az új gazdasági mechanizmus elnevezésű reformcsomag 1968. január 1-jén indult, és a gazdaság racionalizálását, a fogyasztás növelését és az életszínvonal-emelését célozta meg. ${ }^{23}$ Ez két okból volt jelentős tényező. Egyrészt az anyagi javak megteremtése az emberek politikától való távolmaradásának kimondatlan kompromisszumával járt, így fontos legitimációs szerepe volt. Másrészt a reform végrehajtásához Magyarországnak szüksége volt a fejlett, nyugati technológiákra és a tőkére, hiszen a hatvanas évek közepére a külpolitikai egyeztetések során nyilvánvalóvá vált, hogy a Szovjetunió nehezen tudja teljesíteni Magyarország és általában a keleti blokk országainak hitelkéréseit, termény-, élelmiszer- és nyersanyagigényeit (Földes 2015: 59). A gazdasági reformcsomag életben tartása - és ezzel együtt a párt társadalmi támogatottságának fenntartása - mindennél fontosabb tényezője lett a magyar politikai irányításnak. Éppen ezért

${ }^{19}$ A Magyar Szocialista Munkáspárt VIII. kongresszusa, 132. o.

${ }^{20}$ Az MSZMP VIII. kongresszusának határozata a szocializmus építésében elért eredményekről és a párt előtt álló feladatokról (1962. november 20-24.) (Vass - Ságvári 1964: 583).

${ }^{21} \mathrm{Az} 1952$ óta müködő zavaróhálózat technikai elmaradottsága miatt nem volt kielégítő a zavarás hatásfoka, a „baráti” országokból kapott frekvenciazavaró segítség időszakos volt, a zavarni kívánt müsorokat egyre nagyobb teljesítményü adókkal és egyre több hullámhosszon és időben sugározták. A hazai hálózat fenntartása költségesebbé vált, évente 40 millió forintba került. Nem volt egységes politikai iránymutatás arra vonatkozóan, hogy pontosan mely müsorokat kell zavarni. Emellett a pártvezetés úgy ítélte meg, hogy megnövekedett a kormány iránt a bizalom, és nyugalmasnak tekinthető a belpolitikai légkör, ezért úgy vélte, hogy a kapitalista országok állami adásának hangvétele is változott, élük tompult, így inkább a szocializmus építésének eredményeinek propagálására érdemes hangsúlyt fektetni. MOL M-KS 288f. 5/316 ő. e. Az MSZMP Központi Bizottsága Ipari és Közlekedési Osztályának elöterjesztése a rádióvédelem helyzetéről és a Politikai Bizottság vitájának jegyzőkönyve (1963. október).

${ }^{22}$ MOL XIX-J-1-k-USA-18/d-033/1964. 39 d. Külügyminisztériumi feljegyzés a rádióállomások zavarásának megszüntetéséröl (1963. december 14.).

\footnotetext{
${ }^{23}$ A Magyar Szocialista Munkáspárt IX. kongresszusa, Budapest, Kossuth Kiadó, 1966. 117-120. o.
} 
Kádár ettől kezdve az SZKP XII. kongresszusán korábban rögzített, a szocializmus építését megcélzó iránymutatásra hivatkozva tudatosan törekedett arra, hogy a lehető legtöbb szocialista és tőkés országgal felvegye, megjavítsa vagy még szorosabbra füzze a diplomáciai kapcsolatokat. A csehszlovák reformfolyamat kezdetben jó hivatkozási alapnak tünt, mivel Magyarországnak komoly érdekei füződtek ahhoz, hogy Dubček és Brezsnyev között kompromisszum szülessen; Kádár több ízben tárgyalt a CSKP első titkárával a helyi reformok aktuális és jövőbeli helyzetéröl (Békés 2019: 217-225). Ám a prágai tavasz erőszakos leverése után Kádárnak garanciát kellett vállalnia a Szovjetunió felé, hogy Magyarországon kizárólag gazdasági, s nem politikai-társadalmi reformot hajtanak végre (Földes 2015: 97).

A szovjet-magyar viszonyban ettől kezdve Magyarország tudatosan ,a lojális és kiszámítható partner" szerepét játszotta (Békés 2011: 112), és Kádár többször - egyebek között a kommunista pártok 1969-es világkonferenciáján, hazai rendezvényeken és más államszocialista országok nagygyülésein, kongresszusain tartott előadói beszédében és felszólalásában nyilvánosan is kifejezte a Szovjetunió és az SZKP vezetése iránti megkérdőjelezhetetlen elkötelezettségét. A Varsói Szerződés Politikai Tanácskozó Testülete 1969. március 17-én fogadta el a Budapesti nyilatkozatot, amely az európai kontinens, a Szovjetunió és az Egyesült Államok közötti együttmüködést és a kölcsönös tárgyalások rendszeresítését szorgalmazta (Kőváriné 2010: 175). Ez is hozzájárult Magyarország külpolitikai mozgásterének bővítéséhez (Békés 2006).

A kedvező kül- és belpolitikai helyzet hatást gyakorolt a hazai tömegkommunikáció irányítására is: az azt meghatározó alapelvek a korábbi évekhez képest való liberalizálása és az újságírói szakma egyfajta professzionalizációja volt tapasztalható. A Politikai Bizottság (PB) 1965-ben a tájékoztatás javításáról szóló határozatot adott ki. Ebben megfogalmazta, hogy mindenről - így a kedvezőtlen tényekről és az ellentétes véleményekről is - tájékoztatni kell, ugyanis ,a tájékoztatásban nincsen légüres tér, ha mi valamiről nem beszélünk idejében, arról beszél az ellenség." ${ }^{24}$ Ezzel egy időben kifejezték azt is, hogy az MSZMP fenntartja a jogot a tájékoztatás kontextusának meghatározására. Enyhülni látszott az a korábbi évekre jellemző felfogás is, amely szerint a közönséget korlátlanul alakítható és befolyásolható tömegnek kell tekinteni. A tájékoztatás „nyíltsága, őszintesége és teljessége a demokrácia elengedhetetlen tartozéka, a szocialista tudatformálásnak, a tömegek közéleti aktivitásának, a párt és a tömegek közötti bizalomteli kapcsolat erősítésének feltétele." ${ }^{25}$ Vagyis a pártvezetés kezdte felismerni, hogy a politikai legitimáció egyik jelentős tényezője a társadalmi igények, érdekek és visszajelzések figyelembe vétele. A nyilvánosság és a transzparencia felé tett apró lépésként értelmezhető az a rendelkezés, amelynek értelmében a jövőben előzetes közleményt kell kiadni a Központi Bizottság üléseinek napirendjéről, majd az ott elhangzott beszámolókat és hozzászólásokat nyilvánosságra kell hozni. ${ }^{26}$

Míg a központi tájékoztatáspolitikai elvek valamelyest enyhültek, a konkrét ágazati irányításban továbbra is jellemző volt a politikai-hatalmi megközelítésmód (Fricz 1988: 30-31). 1965-ben Szirmai István, az Agitációs és Propaganda Bizottság vezetője a párt tájékoztatáspolitikájának alapelveiről szóló beszédében elmondta, hogy a pártirányítás legfőbb eszköze a politika és a kritika. Hangsúlyozta a közvetett kontrol fontosságát, amelyben a párt nem korlátozó, hanem paternalista szereplőként jelenik meg. Továbbá utalást tett a tájékoztatáspolitika nómenklatúra-rendszeren és az egyszemélyes szerkesztői felelősségen keresztül meg-

\footnotetext{
${ }^{24}$ MOL M-KS 288. f. 5/367 ő. e. Az MSZMP PB határozata a tájékoztatás megjavításáról, 1965. június 8 .

${ }^{25}$ Uo.

${ }^{26}$ Uo.
} 
valósuló irányítására is. ${ }^{27}$ A Tájékoztatási Hivatal 1969-ben országos hatáskört és felügyeleti jogkört szerzett az Magyar Távirati Iroda, a Magyar Rádió és a Magyar Televízió, a Magyar Újságírók Országos Szövetsége és a Lapkiadó Vállalat felett. Ugyanebben az évben bővítették az Agitációs és Propaganda Osztályt: itt a korábbi három helyett már öt alosztály látott el sajtóigazgatási, agitációs, információs, oktatási és tömegpolitikai feladatokat (Takács 2009).

1966-ban a Kulturális Elméleti Munkaközösség Aczél György irányításával kiadta „Az irodalom és a mủvészetek hivatása társadalmunkban" címủ dokumentumot, amely a következőképpen fogalmazott: „,.. az irányításnak ... kell választania: mi az, amit támogat ..., mi az, aminek létéről tudomást vesz és ... mi az, amit elutasít" ${ }^{28}$ Ezzel az állásfoglalással egyértelmüen megszilárdult az a differenciálás, amely az 1958-as művelődéspolitikai alapelvekben és az 1962-es kongresszusi határozatban korábban már felderengett, vagyis az, hogy a kultúr- és tájékoztatáspolitikában a párt által támogatott és tiltott kategóriák mellett létezik egy türt kategória is.

Az újságírói szakma professzionalizációját illetően fontos lépés volt, hogy a Tájékoztatási Hivatal 1967-től szabályzatban rendelkezett az újságírók szükséges felsőfokú végzettségéröl, és ösztönözte idegennyelv-tanulásukat is. 1969-től megkezdte müködését a Magyar Újságírók Országos Szövetségének Felvételi és Minősítő Bizottsága, amely az újságírói gyakornokok pályájáról döntött (Takács 2008: 164). Az amnesztiarendelet a szilenciumra ítélt írók, újságírók és szerkesztők rehabilitációját és újbóli munkába állását eredményezte (Cseh et al. 2004: 282). A politikai kontrol oldódásának hatására bővült a politikamentes, szórakoztató célú kiadványok palettája (Sipos - Takács 2005: 57). Az 1960-as évek második felében nőtt az időszaki periodikák és a napilapok példányszáma, és egyre nagyobb népszerüségre tettek szert a kulturális, és a szabadidős tevékenységgel kapcsolatos lapok (Takács 2008: 161-163).

Lényeges a Tömegkommunikációs Kutatóközpont (TK) 1969-es megalakulása is, ahol számos témában készítettek tömegkommunikáció-elemzéseket és közvélemény-kutatásokat, az intézmény saját negyedéves szakfolyóiratot adott ki, több szakirodalmi tétel lefordításban vett részt és kiterjedt nemzetközi szakmai kapcsolatrendszere volt. (Terestyéni 2010)

\section{A gazdasági problémák elötérbe kerülése (1971-1976)}

A negyedik tájékoztatáspolitikai szakaszt a közvetlen irányítás ismételt elötérbe kerülése jellemezte. A Kádár-korszak első jelentős töréspontja az 1970-es évek első felében jelentkezett (Földes 2018: 199): a magyar pártvezetés abban a tudatban folytatta egyre eredményesebb külpolitikai stratégiáját, hogy az a Szovjetunió teljes támogatását élvezi. Kádár azonban kifejezésre juttatta, hogy ,intenzívebbé kell tenni az európai gazdasági, kereskedelmi, műszakitudományos és kulturális együttmüködéssel kapcsolatos javaslataink kidolgozását" (Földes 2015: 130). Ezzel nyílt vitába került Brezsnyevvel, aki nem támogatta az ilyen sokrétü elköteleződést a nyugati országokkal. 1972 februárjában Brezsnyev több személyes találkozón keményen bírálta a magyar reformokat, és azok felülvizsgálatát kérte. Mivel Kádár nem volt hajlandó felhagyni a reformpolitikával, a magyar pártvezetés manőverezésbe kezdett: a Szovjetuniónak lojalitást, a kérések teljesítését, vagyis a változtatást kommunikálta, míg a belpolitikában éppen ennek az ellenkezőjét hangoztatta: a reform folytatását.

Az új gazdasági mechanizmus az 1970-es évek közepére megrekedt. A világgazdasági folyamatokra az ország lassan reagált, az olajválságok és a hitelfelvételek ellehetetlenítették a

${ }^{27}$ MOL M-KS 288. f. 34/65/17. ő. e. Részlet Szirmai István Ideológiai és kulturális életünk időszerü kérdései címü előadásából (1965. október 8.).

${ }^{28}$ Az irodalom és a müvészetek hivatása társadalmunkban. Az MSZMP Kulturális Elméleti Munkaközösségének Tanulmánya. Társadalmi Szemle, XXI. évf. 7-8. sz. 1966. július-augusztus. 29-58. 
magyar gazdaságot. Az egyre nagyobb nyilvánosságot kapott újbaloldali reformtörekvések és liberális szemléletek - amelyek az államszocializmus müködését is kritikával illették - is éreztették hatásukat; ezekkel szemben egyre eszköztelenebbé vált a magyar vezetés, a párton belül pedig fokozatosan megjelentek a haladási iránnyal kapcsolatos ellentétes vélemények. Kádárt már 1974-ben figyelmeztették a közgazdászok, hogy a gazdaság technológiai fejlesztését és a lakossági fogyasztás növelését egyidejüleg nehezen lehet megvalósítani. Bognár József, az MTA Világgazdasági Kutatóintézet igazgatója azt tanácsolta, hogy „mélyebb és sokoldalúbb tájékoztatást kell adni a lakosságnak, hogy ne érjék őket felkészületlenül »az esetleges takarékoskodási intézkedések «", ám Kádár sem ezt, sem a megszorító intézkedések bevezetését nem vállalta. $^{29}$

A korábbi évek megengedőbb tájékoztatáspolitikájának hatására a belpolitikai újságírás egyre kritikusabb hangvételben számolt be az itthoni kedvezőtlen társadalmi és gazdasági folyamatokról. Ezzel kapcsolatban az Agitációs és Propaganda Bizottság a következőképpen fogalmazta meg véleményét: „Az újságírók sokszor megfeledkeznek arról, hogy a sajtókritika - a széles társadalmi nyilvánosság előtti elmarasztalás - rendkívül súlyos dolog. ... Ha a sajtókritikában teret engedünk az indulatnak és megfeledkezünk az elvtársiasságról, a segítő szándékról, akkor többet ártunk, mint használunk."30 A pártvezetés 1971-ben a sajtó tevékenységét szigorúbb ellenőrzés alá vonta azzal, hogy visszavett a korábbi liberalizációs törekvésből és nyíltan deklarálta elvárásait: „A sajtó akkor szolgálja jól a párt politikáját, ha a rendelkezésre álló eszközökkel mozgósítja a lakosságot ... A tömegtájékoztatás, a közvéleményformálás nagy felelősséget ró a sajtó munkatársaira. ... Törekedjenek a pontosságra a vélt igazságok megírása helyett. Ne csak regisztrálják, hanem formálják, alakítsák a közvéleményt." 31

A Magyar Rádió munkáját illetően kritikaként merült fel, hogy a kedvezőtlen események közlése előtt gyakori a „tétovázás”, a „bizonytalankodás”, és ehhez kapcsolódóan rögzítették azt a felismerést, hogy a késlekedés miatt ,a közönség egy része a nyugati rádióadókra hagyatkozik; ez rontja a tájékoztatás hitelességét." ${ }^{32}$ A kritika a Magyar Televízió politikai müsoraival szemben is megjelent, és a pártvezetés azt kérte, hogy azok „teljes mértékben igazodjanak a párt és a kormány politikájához”, mert „a televízió naponta milliós tömeg gondolkodását és szemléletét alakítja." ${ }^{33}$ Kádár az 1971-es országos újságíró-aktívaértekezleten azt mondta, hogy az újságírók „csak akkor tudják betölteni hivatásukat, ha a szocializmus elkötelezett hívei, annak elveit vallják."34 Vagyis a tájékoztatáspolitikai elvek liberalizációjának egyértelmüen vége szakadt, a párt visszatért a két évtizeddel korábbi álláspontjához, amelynek értelmében a „megfelelö” tájékoztatás az agitátori-propagandista újságírásban gyökerezik.

1974-ben a Minisztertanács rendeletben határozott a Magyar Rádió (MR) és a Magyar Televízió (MTV) intézményi szétválasztásáról, és az Állami Rádió és Televízió Bizottság lét-

${ }^{29}$ MNL OL M-KS 288. f. 47/758. ő. e. Bognár József levele és feljegyzése, 1974. november 1.

${ }^{30}$ Az MSZMP Központi Bizottsága Agitációs és Propaganda Bizottságának állásfoglalása a belpolitikai újságírás helyzetéről és néhány problémájáról (1971. május 21.) (Vass 1983: 68)

${ }^{31}$ Uo. 72-73. o.

${ }^{32}$ Az MSZMP Központi Bizottsága agitációs és propaganda bizottságának állásfoglalása a rádió müsorpolitikájáról, müsorairól és a fejlesztési tervekről (1971. november 23.) (Vass 1978: 152).

${ }^{33}$ Az MSZMP Központi Bizottsága agitációs és propaganda bizottságának állásfoglalása a Magyar Televízió munkájáról (1972. június 6.) (Vass - Fekete 1979: 280-281)

${ }^{34}$ Kádár János felszólalása a Központi Bizottság Agitációs és Propaganda Osztályának országos újságíró-aktívaértekezletén, Népszabadság 1971. november 14. 3. o. 
rehozásáról. A döntés az MR és az MTV komplex politikai irányítását tette lehetővé. A határozat egyértelmüen kijelölte a két intézmény tömegkommunikációban betöltendő feladatát: részt kell venniük a párt politikájának propagálásában, korszerüen és gyorsan kell tájékoztatniuk, továbbá hozzá kell járulniuk a „közművelődési igények színvonalas kielégítéséhez és a szabadidő tartalmas kihasználásának elősegítéséhez." ${ }^{35}$ Az Állami Rádió és Televízió Bizottság döntött az MR és az MTV költségvetési és beruházási terveiről, ellenőrizte azok megvalósulását, rendelkezett a két intézmény hosszú távú müsorterveiről és infrastrukturális fejlesztéséröl, valamint koordinálta az MR és az MTV nemzetközi kapcsolatait.

A Központi Bizottság 1976-ban, a pártpropaganda feladatait összegezve megállapította, hogy „megkülönböztetett figyelmet kell fordítani” az újságírók elméleti felkészítésére és továbbképzésére. A további feladatok között pedig a marxista-leninista müveltség széles körü terjesztését jelölték meg, amelyet elsősorban a rádiótól és a televíziótól várták el tudományosismeretterjesztő müsorok formájában. A pártsajtónak pedig „közvetlenebbül” és „,rendszeresebben" kellett foglalkoznia ideológiai kérdésekkel. ${ }^{36}$

\section{Súlyosbodó gazdasági helyzet és az őszinte kommunikáció iránti igény (1977-1985) ${ }^{37}$}

Az MSZMP XI. kongresszusán minden eddiginél világosabban fogalmazták meg a párt külgazdasági szándékát, vagyis azt, hogy az egyre romló gazdasági helyzetben elengedhetetlen a korábban megkezdett külpolitikai nyitás folytatása: „külpolitikánkban ... az a legfontosabb feladatunk, hogy kedvező külső feltételeket hozzunk létre szocialista építőmunkánk számára." ${ }^{38}$ Kádár 1976-ban a Varsói Szerződés Politikai Tanácskozó Testületének ülésén tartott felszólalásában ennél is tovább ment, és meggyőződését fejezte ki arról, hogy „,a minden területre kiterjedő nyugati együttmüködés nemcsak Magyarország, hanem az egész szocialista tábor érdekét szolgálja" (Földes 2015: 204-205). Magyarország ekkorra már több mint száz országgal állt diplomáciai kapcsolatban, és külkereskedelmének több mint egyharmada fejlett tőkés országokkal zajlott. ${ }^{39}$ 1977-től kezdve a szovjet-amerikai kapcsolatok megélénkülése is hivatkozási alap lett a magyar külpolitikai stratégiában. ${ }^{40}$ Lényeges lépés volt az is, hogy Magyarország 1982-ben a Szovjetunió tudta és beleegyezése nélkül ${ }^{41}$ csatlakozott a Nemzetközi Valutaalaphoz és a Világbankhoz (Földes 2018: 120), ami azt eredményezte, hogy ettől kezdve a Nyugattól való gazdasági függés meghatározóbbá vált, mint a keleti blokkhoz való politikai közelség (Békés 2019: 195). A virágzásnak indult magyar külpolitikai kapcsolatokat 1979 decemberében Afganisztán - a kelet-európai államszocialista országok számára is - vá-

${ }^{35}$ MT határozat az Állami Rádió és Televízió Bizottságról, valamint a Magyar Rádióról és a Magyar Televízióról 1047/1974. (IX. 18.) (Paál 2015: 699).

${ }^{36}$ Az MSZMP Központi Bizottságának határozata a pártpropaganda soron levő feladataira és továbbfejlesztésére (1976. október 26.) (Vass 1983: 317).

${ }^{37}$ Fricz (1988) az ötödik tájékoztatáspolitikai korszakot 1977-től az MSZMP XII. kongresszusáig, vagyis 1980 tavaszáig datálja. Ezzel szemben úgy vélem, hogy ez az átmeneti időszak valójában 1986-ig tartott, mert ettől az évtől kezdve jelentek meg a tényleges, kézzel fogható tájékoztatáspolitikai változások. 1980 és 1986 között csak retorikai szinten valósult meg a tájékoztatáspolitikai irányváltás.

${ }^{38}$ A Magyar Szocialista Munkáspárt XI. kongresszusa (1975. március 17-22.) (Vass 1983: 154).

${ }^{39}$ Uo. 63. o.

${ }^{40}$ Közlemény az MSZMP Központi Bizottságának üléséről (1977. október 20.) (Vass 1983: 551).

${ }^{41}$ Magyarország 1967 óta többször jelezte csatlakozási szándékát a Szovjetuniónak, ám Brezsnyev ezt minden alkalommal elutasította. 
ratlan szovjet megszállása majdnem meghiúsította. Ugyanis a szovjet intervenció veszélybe sodorta a keleti blokk és a nyugati országok diplomáciai, gazdasági és kereskedelmi kapcsolatait, és ezzel komoly válságot vetített elő az ezektől mind inkább függő Magyarországon (Békés 2019: 300-301).

Az 1975-ben aláírt Helsinki-egyezmény a hazai külpolitikai törekvések mellett a hazai sajtópiacnak is kedvezett: egyebek között biztosította a nyugati és a keleti tábor országai közötti sajtótermékcserét, aminek eredményeként itthon - bár korlátozott mennyiségben és korlátozott helyeken, de - egyre többféle nyugati újság jelent meg (Kalmár 2014: 434-435). 1977-ben már több mint negyven, föként a külföldiek által látogatott elárusítóhelyen lehetett nyugati sajtótermékeket venni Magyarországon. A legjellemzőbb a szállodai előfizetés volt, ezt követték a közületi, az intézményi és a vállalati megrendelések (Takács 2020: 30). A helsinki megállapodás garantálta a nyugati rádióadások zavartalan sugárzását is; a magyar technikai berendezéseket 1979-től kezdték leszerelni (Balás B. 2009: 312).

Kádár eltökélt ragaszkodása az életszínvonal-politika tartásához és az egyre kényszeresebbé váló nyugati nyitás politikája hatással volt a magyar tájékoztatáspolitikai alapelvek alakulására is. A rádió és a televízió technikai fejlődése és széles körü elterjedése felgyorsította az információközlést, a nyugati nyitás pedig számos társadalmi, kulturális és életmódbeli hatást gyakorolt a magyar társadalomra. Erre utal az 1977-es, a tájékoztatás továbbfejlesztéséről szóló PB-határozat egyik passzusa is, amelyben megfogalmazták azt, hogy „a turizmus bővülése, a sajtótermékek kölcsönös cseréje, a személyes kapcsolatteremtés növekvő aránya" új követelmények elé állítja a médiairányítást, és megköveteli a hírközlő eszközök és a munkamegosztás fejlesztését. ${ }^{42}$ Ebben a szövegben még megfogalmazódott a média politikai instrumentalizációja, vagyis az, hogy „a tájékoztatás nem cél, hanem eszköz”, amelynek feladata a politikai rendszer „érdekeinek szolgálata” és az emberek „tudatának, magatartásának formálása." ${ }^{23}$ Mégsem ez lett a tájékoztatáspolitikai koncepció fö irányvonala, hanem az, hogy a média olyan hidat képezzen a politikai döntéshozók és a közvélemény között, amely nemcsak „minden lényeges eseményről időben, pontosan” tájékoztat, hanem segíti a „,[politikai] összefüggések, a folyamatok megismerését, a döntések megértését, elfogadását és végrehajtását", és fórumot biztosít „a lakosság közérdekű társadalmi, gazdasági és kulturális kezdeményezéseinek, javaslatainak, bejelentéseinek" is. ${ }^{44}$ A Központi Bizottság egy másik határozatban rögzítette azt is, hogy a megfelelő tájékoztatáshoz elengedhetetlen a szerkesztőségek pártszervekkel való kölcsönös kapcsolata, és az, hogy a párttagok megfelelő ideológiai müveltséggel rendelkezzenek, mert csak így tudnak a kor tájékoztatási kihívásainak megfelelni (Győri 1977: 5-16).

1979-ben megjelent a médiairányításban a tömegkommunikációs eszközök összehangolásának igénye, ami azért lényeges, mert jelzi a médiarendszer müködésének értő jellegü megközelítését. A Politikai Bizottság ekkor fogalmazta meg először az egyes médiumok közötti különbségeket, és ezek alapján differenciálta a hírközlési és propagandafeladatokat. Ennek értelmében a PB a rövid hírciklusú rádiót jelölte ki elsődleges hírközlő médiumnak, a televíziótól a vizuális kommunikáció adta lehetőségek jobb kihasználását kérte, a hosszabb hírciklusú napisajtóval szemben pedig azt az elvárást fogalmazta meg, hogy az egészítse ki, ma-

\footnotetext{
${ }^{42}$ Az MSZMP Központi Bizottsága Politikai Bizottságának határozata a tájékoztatás továbbfejlesztéséröl (1977. szeptember 6.) (Vass 1983: 547).

${ }^{43}$ Uo.

${ }^{44}$ Uo. 547-548. o.
} 
gyarázza, bővítse a rádió és a televízió politikai műsoraiban elhangzott információkat. ${ }^{45} 1981$ től figyelem fordult a körzeti rádióstúdiókra is, amelyekre kettős feladat hárult: a minél szélesebb körü tájékoztatás érdekében össze kellett kapcsolniuk a helyi, regionális ügyeket a központi pártpolitikával, illetve a külföldi rádióállomások vételi körzetében müködő rádióknak feladatuk lett a „nemkívánatos külföldi hatások” ellensúlyozása is. A müsorkínálatot tekintve a szórakoztató, életmód-életvitel-szabadidő témájú műsorokkal, valamint fórum típusú adásokkal - amelyekben az adott téma felelős szakemberei, vezetői válaszolnak a lakosság kérdéseire - kellett jelentkezniük. ${ }^{46}$ Lényeges eleme az 1979-es PB-határozatnak az is, hogy elötérbe került a tájékoztatáspolitikában az a nézet is, amely észleli és értékeli a társadalom sokszínüségét, valamint rögzíti azt is, hogy az egyes médiafogyasztói csoportok megszólításához differenciált információközlésre van szükség. További, jelentős mértékű elmozdulást jelez a korábbi tájékoztatáspolitikai elvektől az a pártiratokban megjelenő új követelmény is, amely tömegkommunikációtól a „lehetőségekhez képest való gyorsaságot”, „pontosságot és hitelességet" várt el. ${ }^{47}$

A média tartalmát illetően is láthatunk változást. A gazdasági problémákról a hetvenes évek közepéig jellemzően csak formális, a lakosság számára kevésbé informatív tájékoztatást lehetett adni, fontos elvárás volt a kedvezőtlen hírek elrejtése, valamint a politikailag, társadalmilag kedvező történések hangsúlyozása. A pártvezetés idővel észlelte, hogy az effajta tájékoztatás nem képes kielégíteni a lakosság információigényét, sőt a túl sok pozitívum kiemelésével a sajtó nem tudja a gazdasági helyzetet reálisan ábrázolni, így ,,az emberek egyes kérdéseket tévesen ítélnek meg". ${ }^{8}$ Ennek érdekében 1977-tól fordulat következett a tájékoztatáspolitikában, amelynek hatására fokozatosan nyilvánosságra kerültek az ország gazdasági problémái, nehézségei is. Igény mutatkozott ,a lakosságot közvetlenül érintő döntések előkészítésének, szükségességének bemutatására, a társadalompolitikai, népgazdasági összefüggések ábrázolására", az alternatíva felmutatására és a vita lehetőségének felkínálására is. ${ }^{49}$ Ám a tömegkommunikáció tartalma továbbra is közvetlen irányítás alatt állt: a felmondás helyett „tervszerü átcsoportosításról”, az áremelés helyett árrendezésről kellett írni, és a sajtónak törekednie kellett arra, hogy a kedvezőtlen híreket ,jó példákkal” ellensúlyozza. ${ }^{50}$

1980-ban az MSZMP XII. kongresszusán szó esett az államszocialista társadalmi viszonyok erősítéséröl és arról, hogy az emberi tényezőnek jelentős szerepe van a szocializmus építésében. Ebből kiindulva a pártkongresszusi határozat elöírta, hogy a tömegkommunikációnak a dolgozó nép művelődését és szórakoztatását kell szolgálnia, és „felelősen részt kell vállalnia a szocialista tudat fejlesztésében, a közvélemény formálásában és a közéleti demokrácia erösítésében." 51 Ezt követően a tájékoztatással kapcsolatos elvárások között hangsúlyos helyen szerepelt a közönség tagoltságának (eltérő szórakozási, kulturálódási, müvelő-

${ }^{45}$ A Politikai Bizottság határozata az agitációs munka helyzetéről, időszerü feladatairól (1979. március 27.) (Vass 1983: 945-946).

${ }^{46}$ Az MSZM KB Agitációs és Propaganda Bizottságának állásfoglalása a vidéki (körzeti) rádiózás helyzetéről és időszerü feladatairól (1981. április 21.) (Vass 1988: 196-197).

${ }^{47}$ A Magyar Szocialista Munkáspárt XII. kongresszusa (1980. március 24-27.) 182. o.

${ }^{48}$ Uo. 940. o.

${ }^{49}$ Az MSZMP Központi Bizottsága Politikai Bizottságának határozata a tájékoztatás továbbfejlesztéséröl (1977. szeptember 6.) (Vass 1983: 546).

${ }^{50}$ A Politikai Bizottság határozata a munkaerő-gazdálkodás javítására hozott intézkedések végrehajtásának kezdeti tapasztalatairól Győr-Sopron megyében (1979. május 29.) (Vass 1983: 1022).

${ }^{51}$ A Magyar Szocialista Munkáspárt XII. kongresszusa (1980. március 24-27.) 182. o. 
dési szokások, iskolázottság, kor) és médiafogyasztási preferenciájának felismerése és célzott kielégítése. 1981-ben ezt így fogalmazták meg: „A témák megválasztásánál és kifejtésénél, az eszközök változatos és összehangolt felhasználásánál messzemenően figyelembe kell venni az egyes rétegek speciális érdeklődését, tapasztalatait és ismereteit." ${ }^{252} 1982$-ben pedig a következőképpen: „A tájékoztatás, az agitáció és a propaganda [...] differenciáltan vegye figyelembe a különböző társadalmi rétegek sajátos igényeit; növelje a lakosság tájékozottságát." 53

Az 1970-es évek második felében elindult, pontosabb, öszintébb hangvételü tájékoztatási törekvés az 1985-ös pártkongresszuson már sokkal nyíltabban fogalmazódott meg: „A szocializmusról korábban alkotott, sok esetben idealizált, esetenként illuzórikus felfogás a mai valóság között eltérés mutatkozik. ... [Az agitáció és a propaganda] sokoldalúan, reálisan világítsa meg a mai valóságot, ennek ellentmondásait, a fejlődés objektív lehetőségeit és korlátait., ${ }^{54}$

Érvelhetünk úgy, hogy az 1970-es évek második felében a pártvezetés észlelte, hogy a gazdasági problémák olyan társadalmi-politikai válsággá fokozódtak, amelyet az MSZMP egyedül már nem volt képes megoldani, így korábbinál is nagyobb szüksége lett a társadalmi támogatásra. A társadalmi párbeszédhez azonban elengedhetetlen volt az emberek pontos tájékoztatása. Ez elmaradt, és a kétirányú kommunikáció sem valósulhatott meg az MSZMP által ellenőrzött nyilvánosságban, mert még ebben az időszakban is domináns volt az a nézet, hogy a tömegkommunikáció elsődleges feladata ,az agitáció, a propaganda és a tömegek meggyőzése a párt politikájának helyességéröl” (Kádár 1983: 14-15). Bár megfogalmazták azt, hogy „nálunk cenzúra nincs, nem is lesz”, ${ }^{55}$ ennek ellenére Kádár János világossá tette a tömegkommunikáció tartalmát illetően az egyes intézmények és szerkesztőségek felelősségét: „Nekik kell törődniük azzal, hogy milyen tömeghatást váltanak ki a müsorok és az írások, különösen, ha politikai és eszmei kérdésekről van szó" (Kádár 1983: 15).

Az 1980-as évek hazai nyilvánosságára döntő hatást gyakorolt az is, hogy az évtized elejétől különféle, a hatalommal szembenálló értelmiségi tömörülések alakultak (Romsics 2010: 528), és egymás után jelentek meg a szamizdatkiadványok is, amelyeknek fontos szerepük volt a demokratikus ellenzék összekovácsolásában (Sükösd 2013, Jakab 2015). A politikai rendszer társadalmi támogatottsága az évtized közepére drasztikusan csökkent, az utolsó évekre pedig válságba került (Nagy 1989). Nem elhanyagolható tényező a tömegkommunikációs eszközök ugrásszerü fejlődése sem: a rádió- és a televíziókészülékek széleskörü elterjedése, a körzeti rádióstúdiók megalakulása, az évtized második felétől előbb a kábel-, majd a műholdas televízióadások, valamint a videomagnó-készülékek megjelenése. Az 1980as évek közepén körülbelül 6 millió rádiókészülék volt a magyar lakosság tulajdonában, a televízió-előfizetők száma közel 3 millió fő volt; a lakosság 95 százaléka hallgatott ekkor rádiót és 94 százaléka nézett televíziót. ${ }^{56}$

${ }^{52}$ Az MSZMP KB Politikai Bizottságának határozata a propaganda és az agitáció időszerü feladatairól (1981. április 28.) (Vass 1988: 201).

${ }^{53}$ Az MSZMP KB Politikai Bizottságának határozata a nemzetközi kérdésekröl folytatott agitáció és propaganda további feladatairól (1982. április 14.) (Vass 1988: 335).

${ }^{54}$ A Magyar Szocialista Munkáspárt XIII. kongresszusa (1985. március 25-28.) (Vass 1988: 118).

${ }^{55}$ Határozat a XII. kongresszus óta végzett munkáról és a párt feladatairól, Társadalmi Szemle, 1983. 38. évf. 5. sz. 31. o.

${ }^{56}$ A Magyar Szocialista Munkáspárt XIII. kongresszusa (1985. március 25-28.) 77. o. 


\section{Médiatörténeti mérföldkövek és politikai összeomlás (1986-1990)}

A magyar tájékoztatáspolitikában döntően az 1980-as évek második felében volt tapasztalható változás. A hazai külpolitikai stratégiát továbbra is a ,szocialista építőmunka” folytatására hivatkozva az újabb diplomáciai kapcsolatok keresése jellemezte. A párt XIII. kongresszusán már azt hangsúlyozták, hogy Magyarország a „különböző társadalmi rendszerü országokkal” is a párbeszéd fenntartására és az együttműködés folytatására törekszik, és külön kiemelték a politikai, gazdasági és kulturális relációk mellett a „más kapcsolatok szélesítésére” való törekvést. ${ }^{57}$ Ugyanakkor az MSZMP-n belül egyre erősödő politikai törésvonalak és a felszínre kerülő véleménykülönbségek, valamint a gazdasági krízis és a fokozódó társadalmi problémák miatt a belpolitikai ügyek váltak hangsúlyossá ebben az időszakban. A magyar államszocialista tájékoztatáspolitika utolsó szakaszát kettősség jellemezte: az MSZMP válságba került, ezzel párhuzamosan több olyan liberalizáló, a nyilvánosság kiszélesedését segítő tájékoztatáspolitikai mérföldkő volt az évtizedben, amelynek megvalósulása elképzelhetetlen lett volna a korábbi években.

1986. szeptember 1-jén lépett hatályba az első sajtótörvény, amely a korábbi pártosság helyett már a pontosságot jelölte meg a sajtó és a hírközlö szervek elsődleges feladataként. Emellett még hitelességet és gyorsaságot várt el a tájékoztatásban, illetve azt, hogy „a sajtó segítse elő a társadalmi jelenségek közötti összefüggések megértését." Egyben leszögezte azt is, hogy „a Magyar Köztársaságban mindenkinek joga van arra, hogy tájékoztatást kapjon szűkebb környezetét, hazáját, a világot érintő kérdésekben." ${ }^{, 58}$ A törvény előrelépést jelentett a korábbi évek sajtószabályozásához képest, mert a jogforrási hierarchia magasabb szintjén, törvényileg rendelkezett a sajtó bizonyos kérdéseiröl (Bayer 2005: 162). De nagy hiányossága volt az, hogy nem definiálta egyértelmúen a párt szerepét a tájékoztatáspolitikában (Takács 2009, 2012). A sajtótörvényre hivatkozva ugyanebben az évben adott ki a Tájékoztatási Hivatal egy rendelkezést, amely lehetővé tette a helyi jellegü önálló rádió- és televíziómüsort készítő stúdiók alapítását. ${ }^{59}$ Ebben kimondták azt is, hogy a kizárólag müsorközlést végző helyi stúdiók alapítása nem engedélyhez kötött, ezeknek csak bejelentési kötelezettségük van. Jelentős elmozdulást jelentett a korábbi, antikapitalista ideológiát képviselő sajtóirányítástól az is, hogy a müsoridő maximum 10 százalékáig megengedett volt a reklámok, hirdetések közzététele is. ${ }^{60}$

1986 nyarán elindult az első hazai kereskedelmi rádió, a Rádió Danubius. Ez volt az első olyan médium, amelynek egyértelmüen a szórakoztatás, s nem a pártpropaganda terjesztése, az MSZMP legitimációjának erősítése volt a célja (Bajomi-Lázár 2005: 29). Nagy jelentőséggel bírt Győrffy Miklós 1982-ben indult Bagoly címü, késő esti rádióműsora, mert ebben számos olyan kényes vagy tiltott témáról lehetett beszélni, amelyről a nappali adásidőben nem (Győrffy 2007: 129, Sipos 2010: 54). A Bagoly 1986-ban, az 1956-os forradalom harmincadik évfordulóján külön adássorozattal jelentkezett, itt hangzott el elöször az első nyilvánosságban a Kádár-korszak egyik legnagyobb tabutémája, Nagy Imre és mártírtársai újratemetésének gondolata (Rangos 2014: 25).

1987-ben jelent meg a Beszélő címü szamizdat kiadvány különszámában a „Társadalmi szerződés, avagy a politikai kibontakozás feltételei" címü írás, amely radikális döntéseket sürgetett - egyebek között: alkotmányosságot, sajtószabadságot, a cenzúra eltörlését, a mun-

\footnotetext{
${ }^{57}$ Uo. 95. o.

58 1986. évi II. törvény a sajtóról $2 \S(1),(3)$.

${ }^{59}$ 2/1986. (IX. 1.) MTH számú rendelkezés a helyi jellegü önálló rádió- és televízióműsort készítő stúdiókról. 109. o.

${ }^{60}$ Uo. 110. o.
} 
kavállalói érdekvédelem rendezését, a szociális biztonság megteremtését -, és addig nem tapasztalt bátorsággal vonta felelösségre Kádár Jánost. (Kis 1987: 4) Ugyanebben az évben volt a lakiteleki találkozó, ahol „A magyarság esélyei” címmel rendszerkritikus értelmiségi tanácskozás zajlott a politikai, gazdasági, társadalmi és kulturális reformok szükségességéről és lehetséges irányairól. Itt hangzott el, hogy „,fordulatra van szükség abban az értelemben, hogy a reformnak totálissá kell válnia, miután a válság is totális" (Agócs - Medvigy 1991: 40).

Szintén 1987-ben civil értelmiségi kezdeményezésként elkészült a „Javaslat a sajtónyilvánosság reformjára” címü tanulmány (továbbiakban „Javaslat”), amelyben a szerzők - társadalomkutatók, egyetemi oktatók, újságírók - a magyar tömegkommunikáció, a tájékoztatáspolitika és a nyilvánosság aktuális helyzetét vizsgálták, javaslatot tettek annak átalakítására, és felvázolták a demokratikus nyilvánosságmodell képét. Bár az elemzés a Hazafias Népfront Társadalompolitikai Tanácsa felkérésére a „Fordulat és Reform” című társadalomtudományi kutatás keretében készült, a politikai vezetésről érdemi válasz nem érkezett rá. ${ }^{61} \mathrm{~A}$ Magyar Újságírók Országos Szövetsége 1987 májusában a szöveget nem találta közlésre alkalmasnak (Gálik 2020: 37). A Közgazdasági Szemle ugyanezen év júniusi számában „Fordulat és reform" címmel vitaanyag jelent meg a gazdasági reformról, amelyben a szerzők a reform társadalmi és politikai alapfeltételei között a nyilvánosság reformját is tárgyalták, és bár nyíltan nem mondták ki, okfejtésük forrása egyértelmüen a „Javaslat” volt. Úgy érveltek, hogy a társadalom tagjainak ,a nyilvánosság, a beleszólás, az érdekképviseleti pluralitás, a képviseleti demokrácia” révén lehetősége lenne ,,a piacgazdaság és az állami magatartás társadalmi ellenőrzésére” (Antal et al. 1987: 660-661). A „Javaslat” első változatát teljes terjedelmében végül 1987-ben a párizsi Irodalmi Újság közölte, majd nem sokkal később a Szabad Európa Rádió szöveghủen ismertette (Gálik 2020: 37). 1988 májusában a magyar társadalomelméleti folyóirat, a Medvetánc mellékletében jelentek meg a „Fordulat és reform” tanulmányok, köztük a „Javaslat” hosszabb, átdolgozott változata, amely egyebek között tételesen felsorolta, majd konkrét példákkal illusztrálta a magyar nyilvánosság müködési hibáit. Végül ugyanebben az évben a Kritika közzé tette az eredeti szöveg kibővített és már radikálisabban fogalmazó változatát (Vásárhelyi - Halmai 1998: 7; Gálik 2020: 38). Ebből például már kikerült az MSZMP hegemóniájának és vezető szerepének elismeréséről szóló paszszus (Szekfü 1998: 50). Figyelemre méltó, hogy bár a szerzők közül többen a Tömegkommunikációs Kutatóközpont munkatársai voltak, az intézet saját tudományos folyóirata nem számolt be a már akkor is jelentősnek számító tanulmányról (Gálik 2020: 39).

A „Javaslat” szövegének alakulása és nyilvánosságra kerülésének folyamata jól illusztrálja a korabeli nyilvánosság müködését, vagyis azt, hogy a fennálló politikai rendszert konstruktív kritikával illető tudományos igényü megjegyzések közzétételének lehetőségei is folyamatosan változtak; a nyilvánosság határai folyamatosan mozgásban voltak, és akár néhány hónap alatti is tágulhattak. Erre utalt Gombár Csaba is, amikor „harmonikázó” nyilvánosságról írt, ami azt fejezi ki, hogy a politikai vezetés hol megengedőbb, hol korlátozóbb volt a nyilvánosság kereteinek kijelölésekor. De - mint folytatja - ebben az irányított, ám egészét

${ }^{61}$ Az MSZMP KB Közgazdasági Munkaközössége 1987 áprilisában megvitatta a Fordulat és reform címü anyagot és úgy találta, hogy a szöveg konstruktív jellegü, tovább gondolásra alkalmas felvetéseket tartalmaz. A munkaközösség egyebek között egyetértett azzal, hogy a gazdasági reformhoz elengedhetetlen a politikai és a társadalmi reform. Az előbbi alatt az intézményi átalakítást és a politikai stílusváltást értették. Utóbbival kapcsolatban kiemelték a társadalom tájékoztatásának, párbeszédbe való bevonásának és a kölcsönös bizalom kiépítésének fontosságát. Ám mindezeket kizárólag az MSZMP politikai irányítása alatt látták megvalósíthatónak. (Az MSZMP KB Közgazdasági Munkaközösségének állásfoglalása a „Fordulat és reform” című tanulmány fő kérdéseiről 1987. április 13.) (Vass 1988: 321-322). 
tekintve folyamatosan bővülö nyilvánosságba fokozatosan átszivárgott a szubkulturális második nyilvánosság is (Gombár 1987: 15-16).

1988. január 14-én parázs vita zajlott a Magyar Újságírók Országos Szövetségének székházában a magyar nyilvánosság és tájékoztatáspolitika helyzetéről (Mélykuti 1988: 38). Ennek eredményeként újságírók, reformközgazdászok, jogászok, politológusok, tömegkommunikációs szakemberek kezdeményezték egy országos egyesületként müködő szervezet, a Nyilvánosság Klub megalapítását (B. E. 1988: 24). Ez végül 1988. október 29-én meg is valósult. Két hónap múlva megjelent egy kritikai hangvételü irodalmi és társadalmi folyóirat, a Hitel.

1988. március 25-én megszünt a Tájékoztatási Hivatal (Wiener 1997). Bő egy évvel ezután, a magánvállalkozások lapkiadási tevékenységének és az egyes lapok gazdasági függetlenedésének köszönhetően összeomlott a magyar sajtópiac két irányító intézménye, a Hírlapkiadó Vállalat és a Lapkiadó Vállalat, ezzel pedig megszűnt a „kétpólusú kiadói rendszer” (Juhász 2005: 116).

A Tömegkommunikációs Kutatóközpont 1988-as, az Országos Tervhivatal felkérésére készített tanulmánya felhívta a figyelmet a tömegkommunikációs eszközrendszerek egyenlötlen fejlettségére, az információtermelés főváros-központúságára, az információtermelés- és továbbítás monopolisztikus és oligopolisztikus jellegére, a tulajdonosi szerepek állami centralizációjára és az új típusú tömegkommunikációs eszközök és technológiák (müholdas és kábeltelevízió, videó, képlemez, teletext, telefax, videotex, személyi számítógépek és szövegszerkesztő programok, szedőgépek és nyomtatók, nyilvános számítógépes adatbázisok, száloptikai kábelek, integrált és digitális hálózatok) körüli szabályozatlanságra és az átfogó kommunikációpolitika hiányára. A szakértők új nézőpontra világítanak rá, amikor világossá teszik, hogy az infokommunikációs eszközök rohamos mértékủ fejlődése új típusú, határokon átívelö, a közönség fogyasztását szem előtt tartó, gazdasági, technológiai, modernizációs koncepciókat is magában foglaló médiapolitikát kíván, amely nem alapulhat korlátozásokon és tiltásokon. ${ }^{62}$

1988 májusában az MSZMP országos pártértekezletén ${ }^{63}$ minden eddiginél világosabban fogalmazták meg a problémákat, vagy azt, hogy a három évvel korábban rögzített hetedik ötéves terv céljai nem valósíthatók meg, a gazdasági helyzet „nem javult, nőtt az ország ... adóssága, erősödött az infláció, növekedtek a lakosság terhei, csökkent az életszínvonal ... ezt a helyzetet ... nagyrészt ... belső okok, tevékenységünk fogyatékosságai idézték elő" ${ }^{64}$ Szó esett arról is, hogy a hibás belpolitikai döntések következtében a lakosság körében növekedett az elégedetlenség, romlott a közhangulat, és csökkent a párt társadalmi támogatottsága. Megoldásként a tájékoztatásban gyorsaságot, pontosságot és rendszerességet vártak el, illetve azt, hogy a társadalmat érintő párthatározatok tartalmáról informálják a lakosságot. Kifejezésre juttatták, hogy a párt kiemelt figyelmet fordít a társadalmi nyilvánosságra, amelyet olyan platformként képzelnek el, ahol lehetőség nyílik a közéleti tájékozódásra, a különböző

${ }^{62}$ A tömegkommunikációs rendszer hosszú távú fejlesztése. Koncepció és variánsok. Jel-Kép 1988/3. sz. $10-12$.

${ }^{63}$ Az esemény jelentőségét jelzi, hogy ez volt a harmadik pártértekezlet a párt történetében; az elsőre 1945-ben a került sor a második világháború utáni újjáépítési feladatok és politikai célok megtárgyalása érdekében, a másodikat 1957-ben tartották a forradalom után kialakult helyzet konszolidálása céljából.

${ }^{64}$ A Magyar Szocialista Munkáspárt országos értekezletének állásfoglalása a párt feladatairól, a politikai intézményrendszer fejlesztéséről (1988. május 20-22.) (Vass 1988: 436-437). 
érdekek és vélemények ütköztetésére és a társadalmi ellenőrzésre. ${ }^{65}$ A nyilvánosság ez utóbbi funkciója új tétel volt a médiairányítási alapelvek között, rögzítése jelezte a demokratizálódási folyamatokat. Figyelemre méltó, hogy ebben a szövegben már csak a pártsajtótól várták el a pártosságot, az MSZMP álláspontjának képviseletét. A pártértekezleten döntés született a politikai megújulásról és a haladási irányról is: a párt a gazdasági nehézségek megoldását a szocializmus megújításában, a hatékony piacgazdaság megteremtésében, a „modernizációra épülő határozottabb” külpolitikai nyitásban, ,a társadalmi önszerveződés jogában” és a politikai pluralizmus létrehozásában látta, ${ }^{66}$ ami minden addiginál határozottabb eltávolodást jelentett a korábbi években müködő államszocialista politikai rendszertöl. A pártértekezletnek további jelentős döntése volt, hogy a személyzeti megújulás keretében Kádár Jánost az MSZMP elnökévé választották, vagyis lényegében megfosztották a párt közvetlen politikai irányításától. ${ }^{67}$ A pártértekezlet a korabeli értelmiségi szerzők szerint döntő jelentőségű volt a magyar nyilvános szférát illetően, mert ezután a „nyilvánosság szempontjából gyökeresen más országgal van dolgunk” (Berend 1989: 50), a sajtó hangja pedig „sokkal nyíltabb és határozottabb lett" (Bihari 1989: 58).

A pártértekezlet döntése nyomán a pártfötitkári feladatokat 1988-ban Grósz Károly vette át, aki a technokrata típusú gazdasági reformokat támogatta, de a politikai rendszer átalakítását nem. A Politikai Bizottság tagjává választották Pozsgay Imrét, aki a politikai rendszer liberalizálását és a többpártrendszer kiépítését sürgette, és szoros kapcsolatot épített ki a „népi-nemzeti” értelmiséggel (Romsics 2010: 532-534). Pozsgay részt vett 1987-ben a demokratikus ellenzék már említett lakiteleki találkozóján, ahol beszédében egyebek között a nyílt és őszinte kritikát, a hibákkal való szembenézést, az értelmiségi reformmozgalom elindítását, valamint a társadalmi bizalom visszaépítését szorgalmazta a „demokratikus szocializmus" megvalósítása érdekében (Agócs - Medvigy 1991: 11-23). A PB-tag Pozsgay később, 1989. január 28-án nyilvánosan, szembemenve az MSZMP által deklarált narratívával, a Magyar Rádió 168 óra című müsorában nyilatkozva az 1956-os forradalmat népfelkelésnek minősítette. $^{68}$

1988 júliusában az Agitációs és Propaganda Bizottság új tájékoztatáspolitikai koncepcióval állt elő, amelynek részeként az év végén a Központi Bizottság az Agitációs és Propaganda Osztályt Társadalompolitikai Osztállyá alakította át. Ezzel megszünt a nyomtatott sajtó és az elektronikus média politikai irányítása (Wiener 1997). A Politikai Bizottság ugyanebben az évben fogadta el a politikai nyilvánosságról, a tájékoztatás megújításáról és a sajtóirányítás módjáról szóló határozatot, amely továbbra is a pártbefolyást hangsúlyozta. (Farkas 1990: 19)

1988 novemberében megválasztották Németh Miklós reformkommunista miniszterelnököt, aki politikai pluralizmust és jogállamiságot sürgetett, és nem zárkózott el a nyugati típusú demokrácia meghonosításától sem (Hovanyecz 2008: 4). A Németh-kormány 1989 nyarán véget vetett az MSZMP laptulajdonlási monopóliumának, eltörölte a lapalapítás engedélykötelezettségét, és frekvenciamoratóriumot hirdetett (Bajomi-Lázár 2005: 31). Augusztusban önálló csatornán elindult a Nap-TV, az első magánkézben lévő tv-stúdió, amely a Magyar Televíziónak is készített adásokat.

${ }^{65}$ Uo. 444. o.

${ }^{66}$ Az MSZMP Központi Bizottságának állásfoglalása a belpolitikai helyzetről és a párt feladatairól (1988. november 1-2.) (Vass 1988: 488).

${ }^{67} \mathrm{https}: / /$ www.arcanum.hu/hu/online-kiadvanyok/TenyekKonyve-tenyek-konyve-1/198946DA/magyarorszag-694A/magyar-szocialista-munkaspart-mszmp-6F91/

${ }^{68}$ Népfelkelés: az utolsó csepp a pohárban. Múlt-Kor, 2009. május 18. 
1989 júniusa és szeptembere között zajlottak a kerekasztal-tárgyalások, amelyek célja a békés demokratikus átmenet volt. Az egyeztetések alatt külön szakbizottság foglalkozott a nyilvánosság és a tájékoztatáspolitika reformjának kérdésével (Bozóki 1990: 30). Az Ellenzéki Kerekasztal álláspontja szerint a békés átmenetet csak a pártatlan médiarendszer biztosíthatta (Sükösd - Cseh 2001: 78). A szakbizottság augusztus 24-én kiadta „A pártatlan tájékoztatás alapelvei"-t, amely az egyes médiumok politikai függetlenségét és pártatlanságát sürgette (Bajomi-Lázár 2005: 30). Október 23-án az Országgyülés módosította az alkotmányt, és kikiáltották a Magyar Köztársaságot (Romsics 2010: 541). November 26-án lezajlott az első országos népszavazás, amelyen a köztársasági elnök választásáról, a munkahelyi pártszervezetek megszüntetéséről, az MSZMP vagyonelszámoltatásáról és a munkásőrség feloszlatásáról született döntés. ${ }^{69}$

A módosított alkotmányban a szólás- és a sajtószabadság biztosítása már az államszocializmusra való hivatkozás és egyéb feltétel nélkül szerepelt (Bayer 2005: 167). 1990 januárjában az országgyülés módosította az 1986-os sajtótörvényt, így már törvényben is engedélyezte a lapalapítást és deklarálta a sajtó szabadságát (Bajomi-Lázár 2005: 31). A Magyar Demokrata Fórum (MDF) és a Szabad Demokraták Szövetsége (SZDSZ) 1990 tavaszán pártközi megállapodásban további változtatásokat rögzített. A sajtószabadságról, illetve az elektronikus médiumokról szóló törvények elfogadását kétharmados többséghez kötötték, megerősítették a frekvenciamoratóriumot, ígéretet tettek arra, hogy a pártpolitikai csatározásokat távol tartják a Magyar Televíziótól, a Magyar Rádiótól és a Magyar Távirati Irodától, továbbá rendelkeztek arról, hogy a közszolgálati médiumok vezető tisztségviselőit konszenzusos alapon nevezik ki (Bajomi-Lázár 2005: 32, Bayer 2005: 167).

\section{Összegzés: a média elvi irányításának változásai}

Kádár Jánosnak az 1956-os hatalomátvétel után sajátos belpolitikai helyzetben kellett rendeznie a magyar politikai, gazdasági és társadalmi viszonyokat. A forradalom eseményeinek hatása alatt álló társadalomban kellett megszereznie és fenntartania saját és pártja széleskörü legitimitását úgy, hogy nyíltan elhatárolódott a korábbi évek diktatórikus vezetésétől, miközben maga is fegyveres erővel került hatalomra. E legitimációs folyamatban fontos szerepet kapott a sajtó: nyílt agitációval és propagandával kellett elősegítenie az államszocialista ideológia terjesztését, részt kellett vennie a társadalom orientálásában és mozgósításában.

A magyar tájékoztatáspolitika az 1960-as évek első felében mutatott elöször elmozdulást az agitátori-propagandista elvárásoktól: ekkor a tömegkommunikáció tájékoztatási és népnevelö funkciókat töltött be. Tényleges eredményeket az évtized második felében láthatunk, amikor a média irányítása a liberalizáció apró jeleit mutatta: differenciálódott a kultúrés a tájékoztatáspolitika, a politikai kontrol enyhülése az újságírói szakma egyfajta professzionalizációjára adott lehetőséget, és megsokszorozódott a szórakoztató kiadványok száma. Bár továbbra is tartotta magát az a nézet, hogy a tömegkommunikáció feladata a marxista-leninista eszmék terjesztése, fokozatosan tudatosodott a pártvezetésben az is, hogy a közönség eltérö igényeket és elvárásokat támaszt a médiával szemben.

Az 1970-es évek első felében a tájékoztatáspolitikai liberalizáció visszaszorult, és újból a határozott pártirányítás került elötérbe. A váltást az indokolta, hogy az államszocialista rendszer keretei között nem lehetett tartani a korábbi években meghirdetett, megengedőbb attitüdöt. Az évtized második felében történt újabb változás, amikor megjelent a tájékoztatáspolitikai elvárások között az őszintébb hangnemben való hírközlés igénye, és tudatosodott, hogy kétirányú kommunikációra van szükség.

\footnotetext{
${ }^{69} 25$ éve volt a négyigenes népszavazás, Múlt-Kor 2014. november 26.
} 
Az 1980-as évek első felében az MSZMP már nyíltan hirdette a differenciált politikai kommunikáció és a hiteles tájékoztatás szükségességét. Tényleges tájékoztatáspolitikai változások csak az 1980-as évek második felében történtek: az első sajtótörvény hatályba lépése után több olyan - föként az értelmiségi tevékenységeknek köszönhető - médiatörténeti mérföldkő volt, amely elősegítette a nyilvánosság kiszélesítését és az ország infokommunikációs felzárkózását.

\section{Következtetések}

A magyar tájékoztatáspolitika alapelveiben (pártosság, a kommunista eszmék terjesztésének elsődlegessége, nagy tömegek elérésének és orientálásának szándéka) és müködésében (pártállami monopólium a médiarendszer müködtetéséhez szükséges összes területen, folyamatos állambiztonsági kontrol, cenzorrendszer és öncenzúra elvárása) mindvégig a tekintélyelvü, szovjet-kommunista típusú sajtómodellt követte. Ám bizonyos hazai jelenségek (az életszínvonal-politika tarthatatlansága és a gazdasági nehézségek mindennapivá válása, az MSZMP belső fragmentációja, a pártpolitika egyre romló társadalmi megítélése) és geopolitikai tényezők (előbb a csehszlovákiai, majd az afganisztáni beavatkozás, a Szovjetunió fokozatos gazdasági kifulladása, a Helsinki-egyezmény aláírása), valamint a külpolitikai stratégia hatására a média feletti politikai ellenörzés folyamatosan változott: hol szigorúbb, hol megengedőbb volt.

A magyar pártkongresszusi határozatok külpolitikai passzusaiból kirajzolódik a nyugati nyitás szándéka és az önállósodásra való törekvés, aminek kezdetben financiális (az 1968-as új gazdasági mechanizmus nevü reformcsomag elindításának segítése), később financiális és politikai-legitimációs okai (a reform folytatása és a pártpolitika támogatottságának életben tartása) voltak. Érvelhetünk úgy, hogy az 1960-as évtized közepétől kezdve már nem kimondottan a Szovjetuniótól való politikai, katonai és gazdasági függés befolyásolta a magyar tájékoztatáspolitikai gyakorlatot, hanem döntően a gazdasági válság és a párt társadalmi legitimációs problémái voltak hatással rá.

Azt is láthatjuk, hogy a tájékoztatáspolitikai alapelvekben megjelenő liberalizációs törekvések jellemzően nem egy tudatosan átgondolt, megújuló tájékoztatáspolitikai koncepció részei, hanem a belpolitikai és a gazdasági problémákra adott, ad hoc döntések eredményei voltak: a pártvezetés számára hamar nyilvánvalóvá vált, hogy a gazdasági krízisről beszélni kell, mielőtt az végzetes politikai és társadalmi válságot okozna. Ám a tájékoztatáspolitika megreformálása a tömegkommunikáció eszközelvű használatához való ragaszkodás miatt nem tudott érdemben kibontakozni. Így az új tendenciák csak retorikai szinten érvényesültek, a média gyakorlati irányításában 1986-ig nem történt jelentős mértékü változás. Ezért a hiteles, pontos és a társadalmat széles körben megszólítani képes tájékoztatás nem valósult meg a Kádár-korszakban.

Tanulmányomban arra vállalkoztam, hogy a lényeges kül- és belpolitikai eseményekkel összefüggésben, az MSZMP hivatalos iratait áttekintve vizsgáljam az 1956 utáni magyar tájékoztatáspolitikát és elhatároljam hat korszakát. A szovjet tájékoztatáspolitika részletekbe menő ismertetésére itt most nem volt lehetőségem. A szovjet tájékoztatáspolitika korszakolása, valamint az ottani paradigmaváltások lehetséges okainak feltárása későbbi kutatások lehetséges tárgyát képezheti. 


\section{IRODALOM}

Agócs Sándor - Medvigy Endre (1991) A magyarság esélyei. A tanácskozás hiteles jegyzökönyve. Lakitelek 1987. szep. 27. Lakitelek: Antalógia - Püski Kiadók.

Antal László - Bokros Lajos - Csillag István - Lengyel László - Matolcsy György (1987) Fordulat és reform. Közgazdasági Szemle, XXXIV. évf., 1537. 6. sz., 642-663.

A tömegkommunikációs rendszer hosszú távú fejlesztése. Koncepció és variánsok. Jel-Kép, 1988, 3. sz. 10-20.

B. E. (1988 szerk.) Nyilvánosság Klub. Egy egyesületi kezdeményezés dokumentumai. Mozgó Világ, 14. évf. 7. sz. 23-35.

Bajomi-Lázár Péter (2005) Médiapolitika. In: Bajomi-Lázár Péter (2005 szerk.) Magyar médiatörténet a késö Kádár-kortól az ezredfordulóig. Budapest, Akadémiai Kiadó. 19-51.

Bajomi-Lázár Péter (2020) A patrónusi-kliensi médiarendszer. Magyarország 2010-2018. Budapest, Napvilág Kiadó.

Bajomi-Lázár, Péter - Balcytiene, Auksè - Dobreva, Alina - Klimkiewicz, Beata (2020) History of the Media in Central and Eastern Europe. In: Arnold, Klaus - Preston, Paschal - Kinnebrock, Susanne (2020 eds.) The Handbook of European Communication History, First Edition. Chichester, John Wiley - Sons Inc. 277-298. https://doi.org/10.1002/9781119161783.ch15

Balás B. Dénes (2009) A távírótól a rádióig. A rádiótechnika története az 1800-as évektöl a II. világháborúig. Budapest, Ad Librum Kiadó.

Bayer Judit (2005) Sajtó- és médiajog. In: Bajomi-Lázár Péter (2005 szerk.) Magyar médiatörténet a késö Kádár-kortól az ezredfordulóig. Budapest, Akadémiai Kiadó. 159-198.

Békés Csaba (2006) A helsinki folyamat hatása a magyar külpolitikai gondolkodásra. In: Pritz Pál - Sipos Balázs - Zeidler Miklós (2006 szerk.) Magyar külpolitikai gondolkodás a 20. században. A VI. Hungarológiai Kongresszus (Debrecen, 2006. augusztus 22-26.) szimpóziumának anyaga. https://mek.oszk.hu/05200/05284/05284.pdf (letöltés: 2020. II. 7.)

Békés Csaba (2011) Magyar külpolitika a bipoláris világban 1945-1991. Külügyi Szemle, 10. évf. 4. sz. 95-127.

Békés Csaba (2019) Enyhülés és emancipáció. Magyarország, a szovjet blokk és a nemzetközi politika 1944-1991. Budapest, Osiris Kiadó.

Berend T. Iván (1989) Magyarország 1988. In: Kurtán Sándor - Sándor Péter - Vass László (1987 szerk.) Magyarország Politikai Évkönyve 1988. Debrecen, Alföldi Nyomda. 4352.

Bihari Mihály (1989) Változások és változatlanságok a politikai intézményrendszerben. In: Kurtán Sándor - Sándor Péter - Vass László (1987 szerk.) Magyarország Politikai Évkönyve 1988. Debrecen, Alföldi Nyomda. 53-60.

Bozóki András (1990) Út a rendszerváltáshoz: az Ellenzéki Kerekasztal. Mozgó-Világ, 16. évf. 8. sz. 23-37.

Bozóki András (1996) Cenzúra és sajtó Magyarországon az 1980-as években. Korunk III. évf. 7. sz. 59-70. 
Brooks, Jeffrey (2000) Thank you, Comrade Stalin! Soviet public culture from revolution to Cold War. Princeton, NJ, Princeton University Press.

Buzinkay Géza (2016) A magyar sajtó és újságírás története a kezdetektöl a rendszerváltásig. Budapest, Wolters Kluwer.

Cseh Gergő Bendegúz - Kalmár Melinda - Pór Edit (1999 szerk.) Zárt, bizalmas, számozott II. Irodalom- sajtó- és tájékoztatáspolitika, 1962-1979 (dokumentumok). Budapest, Osiris Kiadó.

Cseh Gergő Bendegúz - Krahulcsán Zsolt - Müller Rolf - Pór Edit (2004 szerk.) Zárt, bizalmas, számozott. Tájékoztatáspolitika és cenzúra 1956-1963 (dokumentumok). Budapest, Osiris Kiadó.

Darvai Tibor (2015) Az oktatáspolitika változása Magyarországon az 1960-as években. 371378. In: Baska Gabrella - Hegedűs Judit (2015 szerk.) Égi iskolák, földi mühelyek: Tanulmányok a 65 éves Németh András tiszteletére. Budapest, ELTE.

Farkas Zoltán (1990) Hadijelentés - Harcok a sajtó körül. Adalékok egy vitához. Mozgó Világ, 16. évf. 7. sz. 12-32.

Földes György (2015) Kádár János külpolitikája és nemzetközi tárgyalásai, I. kötet. Budapest, Napvilág Kiadó.

Földes György (2018) Ívek és töréspontok. Gazdaság, politika, ideológia 1945 után. Budapest, Napvilág Kiadó.

Fricz Tamás (1988) Az MSZMP és a tömegkommunikáció - a párt hivatalos nézetei a tömegkommunikáció politikai intézményrendszerben betöltött, illetve társadalmi szerepéről az 1957-1986 közötti tájékoztatáspolitikai dokumentumok tükrében. Tömegkommunikációs Kutatóközpont, Alfaprint Nyomdaipari Kisszövetkezet, Budapest, 1988. XX. évfolyam, 3. szám, belső kiadvány.

Gálik Mihály (2020) A Tömegkommunikációs Kutatóközpont és a nyilvánosság reformja az 1980-as évek végén. Jel-Kép 2020/3. sz. 34-44.

Gibbs, Joseph (1999) Gorbachev's Glasnost. The Soviet Media in the First Phase of Perestroika. College Station, Texas A\&M University Press.

Glatz Ferenc (2002) Tudománypolitika. Akadémia és tudománypolitika a volt szocialista országokban 1922-1999. Magyar Tudomány 4. sz. 494-506.

Gombár Csaba (1987) Velleitásaink. Századvég 4-5. sz. 5-26.

Gombár Zsófia (2009) Az 1978-as reformtanterv szerepe a magyar irodalomtanítás történetében, Könyv és nevelés 11 . évf. 1 . sz. http://epa.oszk.hu/01200/01245/00041/gzs_0901. html (letöltés: 2020. II. 6.)

Győrffy Miklós (2007) Ez egy nagy összjáték volt. Rádai Eszter interjúja. In: Bajomi-Lázár Péter - Monori Áron (2007 szerk.) Rendszerváltás és az újságírók. Budapest, Antenna Könyvek. 126-136.

Győri Imre (1977) Emeljük a marxista-leninista oktatás és nevelés színvonalát. In: A pártpropaganda soron lévö feladatai (1977). A Magyar Szocialista Munkáspárt Központi Bizottsága 1976. október 26-ai ülése, Budapest, Kossuth Könyvkiadó. 5-37.

Hallin, Daniel C. - Mancini, Paolo (2004/2008) Médiarendszerek. A média- és politikai rendszerek három modellje. Budapest, Alkalmazott Kommunikációtudományi Intézet.

Hegedűs István (2001) Sajtó és irányítás a Kádár-korszak végén. Médiakutató, 2. sz. 45-60. 
Hovanyecz László (2008) Az átmenet miniszterelnöke. Németh Miklós hatvan éves. Népszabadság LXVI. évf. 20/2. sz. 4.

Jakab Lajos (2015) Szamizdatos emlékeim. Médiakutató, 3. sz. 21-51.

Juhász Gábor (2005) Nyomtatott sajtó. In: Bajomi-Lázár Péter (2005 szerk.) Magyar médiatörténet a késő Kádár-kortól az ezredfordulóig. Budapest, Akadémiai Kiadó. 113-132.

Kádár János (1983) Előadói beszéd a Központi Bizottság április 12-13-i ülésén. Társadalmi Szemle, 38. évf. 5. sz. 3-19.

Kalmár Melinda (2014) Történelmi galaxisok vonzásában. Magyarország és a szovjet rendszer 1945-1990. Budapest, Osiris Kiadó.

Kalmár Melinda (2017) Személyi kultusztól a személyesség kultuszáig. Kultúrpolitika a tömegtársadalmak korában. Konferencia előadás. Kultúra és politika 1956-1989. Tudományos konferencia Aczél György születésének centenáriuma alkalmából, 2017. IX. 28. Politikatörténeti Intézet, Budapest.

Király Béla (2006) A kortárs történész vallomása: a magyar kérdés az ENSZ-ben, 1956-1963 In: Békés Csaba - Kecskés D. Gusztáv (2006 szerk.) A forradalom és a magyar kérdés az ENSZ-ben, 1956-1963. Tanulmányok, dokumentumok és kronológia. Budapest, Magyar ENSZ Társaság. 37-49.

Kis János (1987) Válságban cselekedni. Beszélő, 1. évf. 21. sz. 4-9.

Kőváriné Ignáth Éva (2010) Az 1969-es budapesti nyilatkozat helye az enyhülés időszakában. Külügyi Szemle 2010. nyár. 175-191.

Lázár Guy (1988/2006) A szocialista nyilvánosság történetének alapvonala. Kísérlet. Médiakutató, 7. évf. 1. sz. 23-34.

Lehmann Miklós (1998) Az elidegenedés- és antropológia-vita politikai összefüggései. A marxista filozófia reneszánszától a filozófusperig. http://lehmann.hu/lm/elidegen.pdf (letöltés: 2020. I. 31.)

Lenin, Vlagyimir I. - Sztálin, Joszif V. (1901/1948) A sajtóról. Cikkgyüjtemény. Bukarest, Román Munkáspárt.

Linz, Juan J. - Stepan, Alfred (1996) Problems of Democratic Transition and Consolidation. Southern Europe, South America, and Post-Communist Europe. Baltimore and London, The Johns Hopkins University Press.

McNair, Brian (1991) Glasnost, Perestroika and the Soviet Media. London, Routledge.

Mélykuti Attila (1988) „Sajtószabadság vagy van, vagy nincs.” Tudósítás az újságíró-szövetségben január 14-én lezajlott nyilvánosságvitáról. Mozgó Világ, 1988. 14. évf. 7. sz. 38-46.

Murányi Gábor (2000a) „Súlyos politikai hiba.” Igazoló jelentések a hetvenes évekből. Magyar Média 2000/1. 65-74.

Murányi Gábor (2000b) A szerző ellen erélyesen fel kell lépni - „már csak a szerző érdekében is." Igazoló jelentések a hetvenes és nyolcvanas évekből. II. rész. Magyar Média 2000/2. 56-65.

Nagy Lajos Géza (1989) A kettészakadt társadalom. A lakosság, az értelmiség és saját tagságának képe az MSZMP-röl. Jel-Kép, 4. sz. 52-64.

Rangos Katalin (2014) Az agitprop nem a nyilvánosság - Győrffy Miklóssal hetvenedik születésnapján Rangos Katalin beszélget. Médiakutató, 15. évf. 1. sz. 25-32. 
Romsics Ignác (2010) Magyarország története a XX. században. Budapest, Osiris Kiadó.

Sakwa, Richard (1999) The Rise and Fall of the Soviet Union 1917-1991. London and New York, Routledge.

Siebert, Fredrick S., - Theodore Peterson - Wilbur Schramm (1956/1984) Four Theories of the Press. Urbana \& Chicago, Chicago University Press.

Sipos Balázs - Takács Róbert (2005) Újságírói normák. In Bajomi-Lázár Péter (2005 szerk.) Magyar médiatörténet a késö Kádár-kortól az ezredfordulóig. Budapest, Akadémiai Kiadó. 53-88.

Sipos Balázs (2010) Média és demokrácia Magyarországon. A politikai média jelenkortörténete. Budapest, Napvilág Kiadó.

Sipos Balázs (2015) Szempontok a Horthy-kor és a Kádár-kor nyilvánosságának vizsgálatához-összehasonlításához. Me.Dok: Média-Történet-Kommunikáció, 10 évf. 3. sz. 27-42.

Sükösd Miklós - Cseh Gabriella (2001) A törvény ereje. A médiatörvény értékelése felé. Médiakutató, 2. sz. 75-94.

Sükösd Miklós (2013) A szamizdat mint tiposzféra. Földalatti nyomtatásos kultúra és független politikai kommunikáció a volt szocialista országokban. Médiakutató, 2. sz. 7-26.

Szekfü András (1998) A nyilvánosság: sajtószabadság a demokrácia hétköznapjaiban. In: Vásárhelyi Mária - Halmi Gábor (1998 szerk.) A nyilvánosság rendszerváltása. Budapest, Új Mandátum Könyvkiadó. 49-53.

Takács Róbert (2008) A sajtónyilvánosság szerkezete. Múltunk, 2008/3. 157-172.

Takács Róbert (2009) A sajtóirányítás szervezete a Kádár-korszakban. Médiakutató, 10 évf. 3. sz. http://www.mediakutato.hu/cikk/2009_03_osz/07_sajtoiranyitas_kadar (letöltés: 2019. V. 21.)

Takács Róbert (2012) Politikai újságírás a Kádár-korban. Budapest, Napvilág Kiadó-Politikatörténeti Intézet.

Takács Róbert (2015) A sajtó a Kádár-korszakban. In: Paál Vince (2015 szerk.) A sajtószabadság története Magyarországon 1914-1989. Budapest, Wolters Kluwer. 492-595.

Takács Róbert (2020) „A jó tanuló felel” A magyar külpolitika a Helsinki utáni nemzetközi sajtó- és információs vitákban (1975-1983) I. Helsinkitől Belgrádig. Médiakutató, XXI. évf. 2. sz. 25-35.

Taylor, Brett W. (2013) Glasnost vs. Glasnost': A re-evaluation and reinterpretation of Chernobyl in Soviet media. Dalhousie Journal of Interdisciplinary Management, vol. 9, Spring 2013.

Terestyéni Tamás (2010) Volt egyszer egy Tömegkommunikációs Kutatóközpont... Jel-Kép, 2010, 3-4. 15-20.

Vásárhelyi Mária - Halmai Gábor (1998 szerk.) A nyilvánosság rendszerváltása. Budapest, Új Mandátum Könyvkiadó.

Wiener György (1997) Hatalmi viszonyok és kormányzati struktúra (1988-1994). Eszmélet, 9. évf. 36. szám.

https://www.eszmelet.hu/wiener_gyorgy-hatalmi-viszonyok-es-kormanyzati-struktura-1/ (letöltés: 2020. II. 14.) 


\section{Törvények, rendeletek, határozatok}

1949. évi XX. törvény. A Magyar Népköztársaság Alkotmánya https://net.jogtar.hu/getpdf?docid=94900020.TV\&targetdate=fffffff4\&printTitle=1949. +\%C3\%A9vi+XX.+t\%C3\%B6rv\%C3\%A9ny\&referer=http\%3A//net.jogtar.hu/jr/gen/hj egy_doc.cgi\%3Fdocid\%3D00000001.TXT (letöltés: 2020. II. 3)

2/1986. (IX. 1.) MTH számú rendelkezés a helyi jellegü önálló rádió- és televízióműsort készítő stúdiókról http://nmhh.hu/dokumentum/192018/Magyar_sajtojogi_szabalyok_19491989.pdf 109-111. o. (letöltés: 2020. II. 14.)

26/1959. (V. 1.) Korm. rendelet a sajtóval kapcsolatos egyes kérdésekről. Magyar Közlöny, 49. sz. 1959. május 1. 329-334.

A Magyar Forradalmi Munkás Paraszt Kormány 25/1956. (XII. 19.) számú határozata a Kormány Tájékoztatási Hivatalának megszervezéséről. Magyar Közlöny, 104. sz. 1956. december 19. 603-604.

A Magyar Forradalmi Munkás-Paraszt Kormány 25/1956. (XII. 19.) számú határozata a Kormány Tájékoztatási Hivatalának megszervezéséröl. Magyar Közlöny, 104. sz. 1956. XII. 19. 603-604.

A magyar köztársaság kormányának 11.290/1947. Korm. számú rendelete a sajtótermékek és terjesztésük engedélyezésének ideiglenes rendezése tárgyában.

http://nmhh.hu/dokumentum/192016/Magyar_sajtojogi_szabalyok_19451948.pdf (letöltés: 2020. II. 3)

A Magyar Szocialista Munkáspárt IX. kongresszusa. Budapest, Kossuth Kiadó, 1966.

A Magyar Szocialista Munkáspárt országos értekezletének állásfoglalása a párt feladatairól, a politikai intézményrendszer fejlesztéséröl (1988. május 20-22.) In: Vass Henrik (1994 szerk.) A Magyar Szocialista Munkáspárt határozatai és dokumentumai 1985-1989. Budapest, Interart Stúdió. 436-450.

A Magyar Szocialista Munkáspárt VII. kongresszusa (1959. november 30. - december 5.). Budapest, Kossuth Kiadó, 1959.

A Magyar Szocialista Munkáspárt VIII. kongresszusa, Budapest, Kossuth Kiadó, 1962.

A Magyar Szocialista Munkáspárt XI. kongresszusa (1975. március 17-22.). Budapest, Kossuth Kiadó, 1975.

A Magyar Szocialista Munkáspárt XII. kongresszusa (1980. március 24-27.). Budapest, Kossuth Kiadó, 1980.

A Magyar Szocialista Munkáspárt XIII. kongresszusa (1985. március 25-28.). Budapest, Kossuth Kiadó, 1985.

A Politikai Bizottság határozata a munkaerő-gazdálkodás javítására hozott intézkedések végrehajtásának kezdeti tapasztalatairól Győr-Sopron megyében (1979. május 29.) In: Vass Henrik (1983 szerk.) A Magyar Szocialista Munkáspárt határozatai és dokumentumai 1975-1980. Kossuth Könyvkiadó, Budapest. 1017-1022.

Az irodalom és a müvészetek hivatása társadalmunkban. Az MSZMP Kulturális Elméleti Munkaközösségének Tanulmánya. Társadalmi Szemle, XXI. évf. 7-8. sz. 1966. júliusaugusztus. 29-58. 
Az MSZMP KB Közgazdasági Munkaközösségének állásfoglalása a „Fordulat és reform” címü tanulmány fő kérdéseiröl (1987. április 13.) In: Vass Henrik (1994 szerk.) A Magyar Szocialista Munkáspárt határozatai és dokumentumai 1985-1989. Budapest, Interart Stúdió. 315-322.

Az MSZMP KB mellett müködő kultúrpolitikai munkaközösség állásfoglalása néhány társadalomkutató antimarxista nézeteiről (1973). Filozófiai Szemle, 1-2. sz. 159-169.

Az MSZMP KB Politikai Bizottságának határozata a nemzetközi kérdésekről folytatott agitáció és propaganda további feladatairól (1982. április 14.) In: Vass Henrik (1988 szerk.) A Magyar Szocialista Munkáspárt határozatai és dokumentumai 1980-1985. Budapest, Kossuth Kiadó. 333-339.

Az MSZMP KB Politikai Bizottságának határozata a propaganda és az agitáció időszerü feladatairól (1981. április 28.) In: Vass Henrik (1988 szerk.) A Magyar Szocialista Munkáspárt határozatai és dokumentumai 1980-1985. Budapest, Kossuth Kiadó. 199-204.

Az MSZMP Központi Bizottsága Agitációs és Propaganda Bizottságának állásfoglalása a belpolitikai újságírás helyzetéről és néhány problémájáról (1971. május 21.) In: Vass Henrik (1983 szerk.) A Magyar Szocialista Munkáspárt határozatai és dokumentumai 19751980. Kossuth Könyvkiadó, Budapest. 65-76.

Az MSZMP Központi Bizottsága agitációs és propaganda bizottságának állásfoglalása a rádió müsorpolitikájáról, müsorairól és a fejlesztési tervekről (1971. november 23.) In: Vass Henrik (1978 szerk.) A Magyar Szocialista Munkáspárt határozatai és dokumentumai 1971-1975. Kossuth Könyvkiadó, Budapest. 149-159.

Az MSZMP Központi Bizottsága Politikai Bizottságának határozata a tájékoztatás továbbfejlesztéséről (1977. szeptember 6.) In: Vass Henrik (1983 szerk.): A Magyar Szocialista Munkáspárt határozatai és dokumentumai 1975-1980. Kossuth Könyvkiadó, Budapest. 544-550.

Az MSZMP Központi Bizottsága Politikai Bizottságának határozata a sajtó helyzetéről, feladatairól (1958. január 21.) In: Vass Henrik - Ságvári Ágnes (1964 szerk.) MSZMP határozatai és dokumentumai 1956-1962. Budapest, Kossuth Kiadó. 163-169.

Az MSZMP Központi Bizottsága Politikai Bizottságának határozata az agitációs munka helyzetéről, időszerű feladatairól (1979. március 27.) In: Vass Henrik (1983 szerk.) A Magyar Szocialista Munkáspárt Határozatai és Dokumentumai 1975-1980. Budapest, Kossuth Kiadó. 939-947.

Az MSZMP Központi Bizottságának állásfoglalása a belpolitikai helyzetről és a párt feladatairól (1988. november 1-2.) In Vass Henrik (1994 szerk.) A Magyar Szocialista Munkáspárt határozatai és dokumentumai 1985-1989. Budapest, Interart Stúdió. 483-490.

Az MSZMP Központi Bizottságának határozata a pártpropaganda soron levő feladataira és továbbfejlesztésére (1976. október 26.) In: Vass Henrik (1983 szerk.) A Magyar Szocialista Munkáspárt határozatai és dokumentumai 1975-1980. Kossuth Könyvkiadó, Budapest. 301-318.

Az MSZMP Mủvelődési Politikájának Irányelvei (1958. július 25.) In: Vass Henrik - Ságvári Ágnes (1964 szerk.) MSZMP határozatai és dokumentumai 1956-1962. Budapest, Kossuth Kiadó. 276-309.

Az MSZMP PB határozata a sajtó helyzetéröl és feladatairól, 1958. január 21. In: Vass Henrik - Ságvári Ágnes (1964 szerk.) MSZMP határozatai és dokumentumai 1956-1962. Budapest, Kossuth Kiadó. 172-178. 
Az MSZMP Politikai Bizottságának 1977. szeptember 6-i határozata a tájékoztatás továbbfejlesztéséröl In: Vass Henrik (1983) A Magyar Szocialista Munkáspárt határozatai és dokumentumai: 1975-1980. Budapest, Kossuth Kiadó. 544-550.

Az MSZMP VIII. kongresszusának határozata a szocializmus építésében elért eredményekről és a párt előtt álló feladatokról (1962. november 20-24.) Vass Henrik - Ságvári Ágnes (1964 szerk.) A Magyar Szocialista Munkáspárt Határozatai és dokumentumai 19561962. Budapest, Kossuth Könyvkiadó. 559-592.

Az SZKP XXII. kongresszusa, Párttörténeti Közlemények. Az MSZMP Központi Bizottsága Párttörténeti Intézetének Folyóirata, VII. évf. 4. sz. 1961. november 1-4.

Az SZKP XXII. kongresszusa. Párttörténeti Közlemények. Az MSZMP Központi Bizottsága Párttörténeti Intézetének Folyóirata, VII. évf. 4. sz. 1961. november, 1-4.

Határozat a XII. kongresszus óta végzett munkáról és a párt feladatairól. Társadalmi Szemle, 1983. 38. évf. 5. sz. 31.

Kádár János felszólalása a Központi Bizottság Agitációs és Propaganda Osztályának országos újságíró-aktívaértekezletén. Népszabadság 1971. november 14. 3-4.

Közlemény az MSZMP Központi Bizottságának üléséről (1977. október 20.). In: Vass Henrik (1983) A Magyar Szocialista Munkáspárt határozatai és dokumentumai: 1975-1980. Budapest, Kossuth Kiadó. 551-561.

MT határozat az Állami Rádió és Televízió Bizottságról, valamint a Magyar Rádióról és a Magyar Televízióról 1047/1974. (IX. 18.) In: Paál Vince (2015 szerk.) A magyarországi médiaháború története. Média és politika 1989-2010. Budapest, Complex Kiadó. 699.

\section{Levéltári források}

ÁBTL-4.2.-1963. évi 4. tvr. a közkegyelem gyakorlásáról

MOL M-KS 288. f. 34/65/17. ő. e. Részlet Szirmai István Ideológiai és kulturális életünk időszerü kérdései címü előadásából (1965. október 8.)

MOL M-KS 288. f. 5/367 ő. e. Az MSZMP PB határozata a tájékoztatás megjavításáról, 1965. június 8 .

MOL M-KS 288f. 5/316 ö. e. Az MSZMP Központi Bizottsága Ipari és Közlekedési Osztályának előterjesztése a rádióvédelem helyzetéről és a Politikai Bizottság vitájának jegyzőkönyve (1963. október)

MOL XIX-J-1-k-USA-18/d-033/1964. 39 d. Külügyminisztériumi feljegyzés a rádióállomások zavarásának megszüntetéséről (1963. december 14.)

MNL OL M-KS 288. f. 47/758. ő. e. Bognár József levele és feljegyzése, 1974. november 1.

\section{Internetes oldalak}

25 éve volt a négyigenes népszavazás, Múlt-Kor 2014. november 26. 18:58 MTI https://mult-kor.hu/25-eve-volt-a-negyigenes-nepszavazas-20141126 (letöltés: 2020. II. 18.)

Az Alkotmány és módosításai 1988. január 1.-2008. december 31. http://www.politikaievkonyv.hu/online/mp20/2-01.html (letöltés: 2020. II. 18.) 
Népfelkelés: az utolsó csepp a pohárban. Múlt-Kor, 2009. május 18. 12:09.

https://mult-kor.hu/20090518_nepfelkeles_az_utolso_csepp_a_poharban (letöltés: 2020. II. 18.)

Tények Könyve 1989 Magyarország https://www.arcanum.hu/hu/online-kiadvanyok/TenyekKonyve-tenyek-konyve-1/198946DA/magyarorszag-694A/magyar-szocialista-munkaspart-mszmp-6F91/ 